4

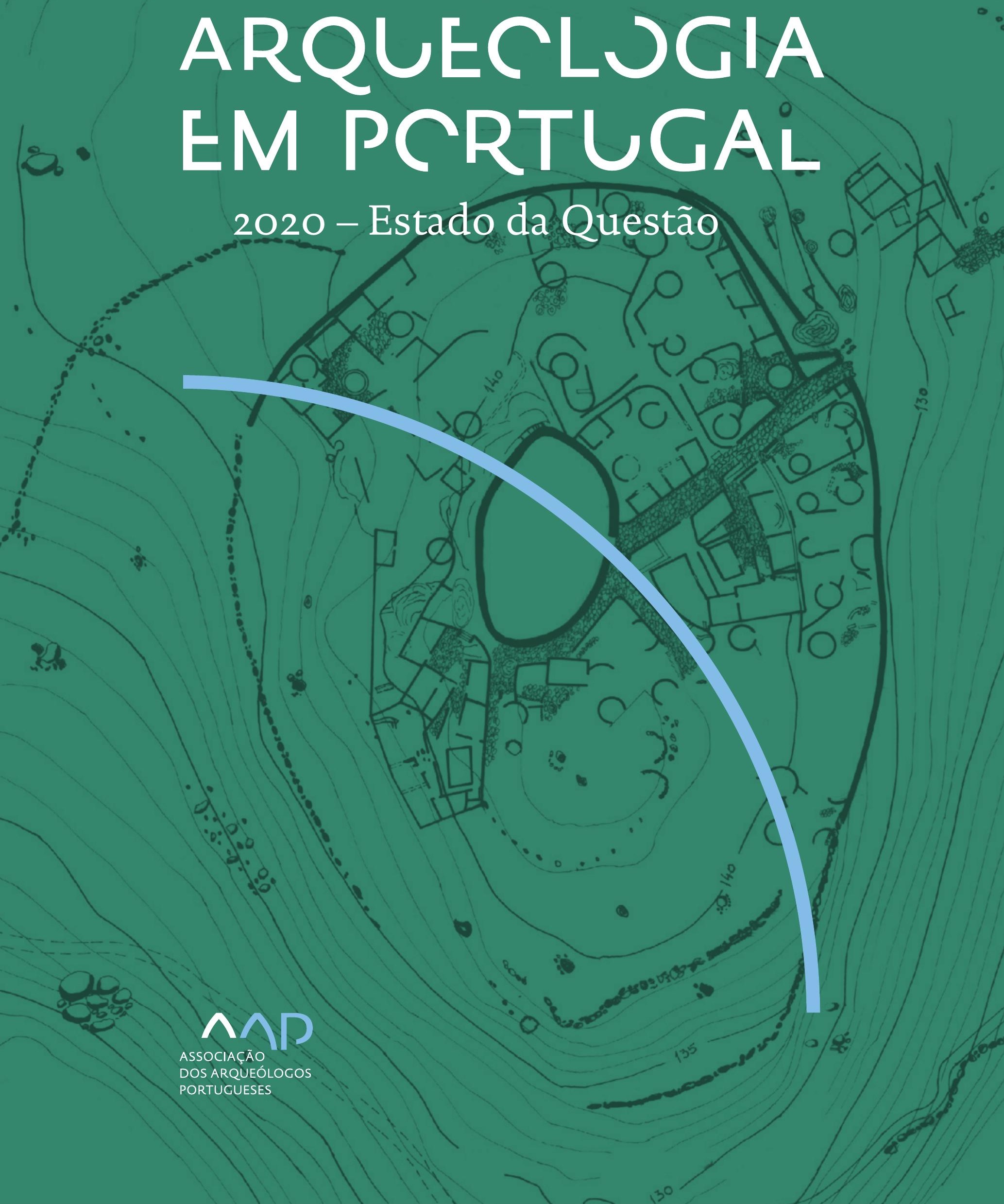


Coordenação editorial: José Morais Arnaud, César Neves e Andrea Martins Design gráfico: Flatland Design

AAP - ISBN: 978-972-9451-89-8

CITCEM - ISBN: 978-989-8970-25-1

Associação dos Arqueólogos Portugueses e CITCEM

Lisboa, 2020

O conteúdo dos artigos é da inteira responsabilidade dos autores. Sendo assim a Associação dos Arqueólogos Portugueses declina qualquer responsabilidade por eventuais equívocos ou questões de ordem ética e legal.

Desenho de capa:

Planta do castro de Monte Mozinho (Museu Municipal de Penafiel).

\section{$\hat{\wedge} \mathrm{P}$}

DOS ARQUEÓLOGOS PORTUGUESES

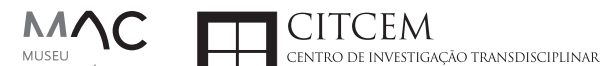
MUSEU
ARQUELLÓGICO
DO CARMO
U.PORTO

FLUP FACULDADE DE LETRAS
UNIVERSIDADE DO PORTO

Apoio

EC para a Ciência 


\section{Índice}

15 Prefácio

José Morais Arnaud

\section{Historiografia e Teoria}

17 Território, comunidade, memória e emoção: a contribuição da história da arqueologia (algumas primeiras e breves reflexões)

Ana Cristina Martins

25 Como descolonizar a arqueologia portuguesa?

Rui Gomes Coelho

41 Arqueologia e Modernidade: uma revisitação pessoal e breve de alguns aspetos da obra homónima de Julian Thomas de 2004

Vítor Oliveira Jorge

57 Dados para a História das Mulheres na Arqueologia portuguesa, dos finais do século XIX aos inícios do século XX: números, nomes e tabelas

Filipa Dimas / Mariana Diniz

73 Retractos da arqueologia portuguesa na imprensa: (in)visibilidades no feminino

Catarina Costeira / Elsa Luís

85 Arqueologia e Arqueólogos no Norte de Portugal Jacinta Bugalhão

101 Vieira Guimarães (1864-1939) e a arqueologia em Tomar: uma abordagem sobre o território e as gentes

João Amendoeira Peixoto / Ana Cristina Martins

115 Os memoráveis? A arqueologia algarvia na imprensa nacional e regional na presente centúria (2001-2019): características, visões do(s) passado(s) e a arqueologia

enquanto marca

Frederico Agosto / João Silva

129 A Evolução da Arqueologia Urbana e a Valorização Patrimonial no Barlavento Algarvio: Os casos de Portimão e Silves

Artur Mateus / Diogo Varandas / Rafael Boavida

\section{Gestão, Valorização e Salvaguarda do Património}

145 O Caderno Reivindicativo e as condições de trabalho em Arqueologia Miguel Rocha / Liliana Matias Carvalho / Regis Barbosa / Mauro Correia / Sara Simões / Jacinta Bugalhão / Sara Brito / Liliana Veríssimo Carvalho / Richard Peace / Pedro Peça / Cézer Santos

155 Os Estudos de Impacte Patrimonial como elemento para uma estratégia sustentável de minimização de impactes no âmbito de reconversões agrícolas Tiago do Pereiro

165 Salvaguarda de Património arqueológico em operações florestais: gestão e sensibilização Filipa Bragança / Gertrudes Zambujo / Sandra Lourenço / Belém Paiva / Carlos Banha / Frederico Tatá Regala / Helena Moura / Jacinta Bugalhão / João Marques / José Correia / Pedro Faria / Samuel Melro

179 Os valores do Património: uma investigação sobre os Sítios Pré-históricos de Arte Rupestre do Vale do Rio Côa e de Siega Verde José Paulo Francisco 
189 Conjugando recursos arqueológicos e naturais para potenciar as visitas ao Geoparque Litoral de Viana do Castelo (Noroeste de Portugal)

Hugo A. Sampaio / Ana M.S. Bettencourt / Susana Marinho / Ricardo Carvalhido

203 Áreas de Potencial Arqueológico na Região do Médio Tejo: Modelo Espacial Preditivo Rita Ferreira Anastácio / Ana Filipa Martins / Luiz Oosterbeek

223 Património Arqueológico e Gestão Territorial: O contributo da Arqueologia para a revisão do PDM de Avis

Ana Cristina Ribeiro

237 A coleção arqueológica do extinto Museu Municipal do Porto - Origens, Percursos e Estudos

Sónia Couto

251 Valpaços - uma nova carta arqueológica

Pedro Pereira / Maria de Fátima Casares Machado

263 Arqueologia na Cidade de Peniche

Adriano Constantino / Luís Rendeiro

273 Arqueologia Urbana: a cidade de Lagos como caso de Estudo Cátia Neto

285 Estratégias de promoção do património cultural subaquático nos Açores. O caso da ilha do Faial

José Luís Neto / José Bettencourt / Luís Borges / Pedro Parreira

297 Carta Arqueológica da Cidade Velha: Uma primeira abordagem

Jaylson Monteiro / Nireide Tavares / Sara da Veiga / Claudino Ramos / Edson Brito /

Carlos Carvalho / Francisco Moreira / Adalberto Tavares

311 Antropologia Virtual: novas metodologias para a análise morfológica e funcional Ricardo Miguel Godinho / Célia Gonçalves

\section{Didáctica da Arqueologia}

327 Como os projetos de Arqueologia podem contribuir para uma comunidade culturalmente mais consciente Alexandra Figueiredo / Claúdio Monteiro / Adolfo Silveira / Ricardo Lopes

337 Educação Patrimonial - Um cidadão esclarecido é um cidadão ativo! Ana Paula Almeida

351 A aproximação da Arqueologia à sala de aula: um caso de estudo no $3^{\circ}$ ciclo do Ensino Básico Luís Serrão Gil

363 Arqueologia 3.o - Pensar e comunicar a Arqueologia para um futuro sustentável Mónica Rolo

377 “Conversa de Arqueólogos" - Divulgar a Arqueologia em tempos de Pandemia Diogo Teixeira Dias

389 Escola Profissional de Arqueologia: desafios e oportunidades Susana Nunes / Dulcineia Pinto / Júlia Silva / Ana Mascarenhas

399 Os Museus de Arqueologia e os Jovens: a oferta educativa para o público adolescente Beatriz Correia Barata / Leonor Medeiros

411 O museu universitário como mediador entre a ciência e a sociedade: o exemplo da secção de arqueologia no Museu de História Natural e da Ciência da Universidade do Porto (MHNC-UP)

Rita Gaspar 
421 Museu de Lanifícios: Real Fábrica de Panos. Atividades no âmbito da Arqueologia Beatriz Correia Barata / Rita Salvado

427 Arqueologia Pública e o caso da localidade da Mata (Torres Novas) Cláudia Manso / Ana Rita Ferreira / Cristiana Ferreira / Vanessa Cardoso Antunes

431 Do sítio arqueológico ao museu: um percurso (também) didático Lídia Fernandes

447 Estão todos convidados para a Festa! E para dançar também... O projecto do Serviço Educativo do Museu Arqueológico do Carmo na $5^{\underline{a}}$ Edição da Festa da Arqueologia Rita Pires dos Santos

459 O “Clã de Carenque”, um projeto didático de arqueologia Eduardo Gonzalez Rocha

469 Mediação cultural: peixe que puxa carroça nas Ruínas Romanas de Troia Inês Vaz Pinto / Ana Patrícia Magalhães / Patrícia Brum / Filipa Santos

481 Didática Arqueológica, experiências do Projeto Mértola Vila Museu Maria de Fátima Palma / Clara Rodrigues / Susana Gómez / Lígia Rafael

\section{Arte Rupestre}

497 Os inventários de arte rupestre em Portugal Mila Simões de Abreu

513 O projeto FIRST-ART - conservação, documentação e gestão das primeiras manifestações de arte rupestre no Sudoeste da Península Ibérica: as grutas do Escoural e Maltravieso Sara Garcês / Hipólito Collado / José Julio García Arranz / Luiz Oosterbeek / António Carlos Silva / Pierluigi Rosina / Hugo Gomes / Anabela Borralheiro Pereira / George Nash / Esmeralda Gomes / Nelson Almeida / Carlos Carpetudo

523 Trabalhos de documentação de arte paleolítica realizados no âmbito do projeto PalæoCôa André Tomás Santos / António Fernando Barbosa / Luís Luís / Marcelo Silvestre / Thierry Aubry

537 Imagens fantasmagóricas, silhuetas elusivas: as figuras humanas na arte do Paleolítico Superior da região do Côa Mário Reis

$55^{1}$ Os motivos zoomórficos representados nas placas de tear de Vila Nova de São Pedro (Azambuja, Portugal) Andrea Martins / César Neves / José M. Arnaud / Mariana Diniz

571 Arte Rupestre do Monte de Góios (Lanhelas, Caminha). Síntese dos resultados dos trabalhos efectuados em 2007-2009 Mário Varela Gomes

599 Gravuras rupestres de barquiformes no Monte de S. Romão, Guimarães, Noroeste de Portugal Daniela Cardoso

613 Círculos segmentados gravados na Bacia do Rio Lima (Noroeste de Portugal): contributos para o seu estudo Diogo Marinho / Ana M.S. Bettencourt / Hugo Aluai Sampaio

631 Equídeos gravados no curso inferior do Rio Mouro, Monção (NW Portugal). Análise preliminar Coutinho, L.M. / Bettencourt, A.M.S / Sampaio, Hugo A.S

645 Paletas na Arte Rupestre do Noroeste de Portugal. Inventário preliminar Bruna Sousa Afonso / Ana M. S. Bettencourt / Hugo A. Sampaio 


\section{Pré-História}

661 O projeto Miño/Minho: balanço de quatro anos de trabalhos arqueológicos Sérgio Monteiro-Rodrigues / João Pedro Cunha-Ribeiro / Eduardo Méndez-Quintas / Carlos Ferreira / Pedro Xavier / José Meireles / Alberto Gomes / Manuel Santonja / Alfredo Pérez-González

677 A ocupação paleolítica da margem esquerda do Baixo Minho: a indústria lítica do sítio de Pedreiras 2 (Monção, Portugal) e a sua integração no contexto regional Carlos Ferreira / João Pedro Cunha-Ribeiro / Sérgio Monteiro-Rodrigues / Eduardo Méndez-Quintas / Pedro Xavier / José Meireles / Alberto Gomes / Manuel Santonja / Alfredo Pérez-González

693 O sítio acheulense do Plistocénico médio da Gruta da Aroeira Joan Daura / Montserrat Sanz / Filipa Rodrigues / Pedro Souto / João Zilhão

703 As sociedades neandertais no Barlavento algarvio: modelos preditivos com recurso aos SIG

Daniela Maio

715 A utilização de quartzo durante o Paleolítico Superior no território dos vales dos rios Vouga e Côa

Cristina Gameiro / Thierry Aubry / Bárbara Costa / Sérgio Gomes / Luís Luís / Carmen Manzano / André Tomás Santos

733 Uma perspetiva diacrónica da ocupação do concheiro do Cabeço da Amoreira (Muge, Portugal) a partir da tecnologia lítica Joana Belmiro / João Cascalheira / Célia Gonçalves

745 Novos dados sobre a Pré-história Antiga no concelho de Palmela. A intervenção arqueológica no sítio do Poceirão I

Michelle Teixeira Santos

757 Problemas em torno de Datas Absolutas Pré-Históricas no Norte do Alentejo Jorge de Oliveira

771 Povoamento pré-histórico nas áreas montanhosas do NO de Portugal: o Abrigo 1 de Vale de Cerdeira Pedro Xavier / José Meireles / Carlos Alves

783 Apreciação do povoamento do Neolítico Inicial na Baixa Bacia do Douro. A Lavra I (Serra da Aboboreira) como caso de estudo Maria de Jesus Sanches

797 O Processo de Neolitização na Plataforma do Mondego: os dados do Sector C do Outeiro dos Castelos de Beijós (Carregal do Sal)

João Carlos de Senna-Martinez / José Manuel Quintã Ventura / Andreia Carvalho / Cíntia Maurício

823 Novos trabalhos na Lapa da Bugalheira (Almonda, Torres Novas) Filipa Rodrigues / Pedro Souto / Artur Ferreira / Alexandre Varanda / Luís Gomes / Helena Gomes / João Zilhão

837 A pedra polida e afeiçoada do sítio do Neolítico médio da Moita do Ourives (Benavente, Portugal)

César Neves

857 Casal do Outeiro (Encarnação, Mafra): novos contributos para o conhecimento do povoamento do Neolítico final na Península de Lisboa.

Cátia Delicado / Carlos Maneira e Costa / Marta Miranda / Ana Catarina Sousa

873 Stresse infantil, morbilidade e mortalidade no sítio arqueológico do Neolítico Final/ Calcolítico ( $4^{\circ}$ e $3^{\circ}$ milénio a.C.) do Monte do Carrascal 2 (Ferreira do Alentejo, Beja) Liliana Matias de Carvalho / Sofia N. Wasterlain 
885 Come together: O Conjunto Megalítico das Motas (Monção, Viana do Castelo) e as expressões Campaniformes do Alto Minho Ana Catarina Basílio / Rui Ramos

899 Trabalhos arqueológicos no sítio Calcolítico da Pedreira do Poio Carla Magalhães / João Muralha / Mário Reis / António Batarda Fernandes

913 O sítio arqueológico de Castanheiro do Vento. Da arquitectura do sítio à arquitectura de um território João Muralha Cardoso

925 Estudo zooarqueológico das faunas do Calcolítico final de Vila Nova de São Pedro (Azambuja, Portugal): Campanhas de 2017 e 2018 Cleia Detry / Ana Catarina Francisco / Mariana Diniz / Andrea Martins / César Neves / José Morais Arnaud

943 As faunas depositadas no Museu Arqueológico do Carmo provenientes de Vila Nova de São Pedro (Azambuja): as campanhas de 1937 a 1967 Ana Catarina Francisco / Cleia Detry / César Neves / Andrea Martins / Mariana Diniz / José Morais Arnaud

959 Análise funcional de material lítico em sílex do castro de Vila Nova de S. Pedro (Azambuja, Portugal): uma primeira abordagem Rafael Lima

971 O recinto da Folha do Ouro 1 (Serpa) no contexto dos recintos de fossos calcolíticos alentejanos

António Carlos Valera / Tiago do Pereiro / Pedro Valério / António M. Monge Soares

\section{Proto-História}

987 Produção de sal marinho na Idade do Bronze do noroeste Português. Alguns dados para uma reflexão

Ana M. S. Bettencourt / Sara Luz / Nuno Oliveira / Pedro P. Simões / Maria Isabel C. Alves / Emílio Abad-Vidal

1001 A estátua-menir do Pedrão ou de São Bartolomeu do Mar (Esposende, noroeste de Portugal) no contexto arqueológico da fachada costeira de entre os rios Neiva e Cávado Ana M. S. Bettencourt / Manuel Santos-Estévez / Pedro Pimenta Simões / Luís Gonçalves

1015 O Castro do Muro (Vandoma/Baltar, Paredes) - notas para uma biografia de ocupação da Idade do Bronze à Idade Média

Maria Antónia D. Silva / Ana M. S. Bettencourt / António Manuel S. P. Silva / Natália Félix

1031 Do Bronze Final à Idade Média - continuidades e hiatos na ocupação de Povoados em Oliveira de Azeméis João Tiago Tavares / Adriaan de Man

1041 As faunas do final da Idade do Bronze no Sul de Portugal: leituras desde o Outeiro do Circo (Beja)

Nelson J. Almeida / Íris Dias / Cleia Detry / Eduardo Porfírio / Miguel Serra

1055 A Espada do Monte das Oliveiras (Serpa) - uma arma do Bronze Pleno do Sudoeste Rui M. G. Monge Soares / Pedro Valério / Mariana Nabais / António M. Monge Soares

1065 São Julião da Branca (Albergaria-a-Velha) - Investigação e valorização de um povoado do Bronze Final

António Manuel S. P. Silva / Paulo A. P. Lemos / Sara Almeida e Silva / Edite Martins de Sá

1083 Do castro de S. João ao Mosteiro de Santa Clara: notícia de uma intervenção arqueológica, em Vila do Conde Rui Pinheiro 
1095 O castro de Ovil (Espinho), um quarto de século de investigação - resultados e questões em aberto

Jorge Fernando Salvador / António Manuel S. P. Silva

1111 O Castro de Salreu (Estarreja), um povoado proto-histórico no litoral do Entre Douro e Vouga

Sara Almeida e Silva / António Manuel S. P. Silva / Paulo A. P. Lemos / Edite Martins de Sá

1127 Castro de Nossa Senhora das Necessidades (Sernancelhe): uma primeira análise artefactual Telma Susana O. Ribeiro

${ }_{1141}$ A cividade de Bagunte. O estado atual da investigação Pedro Brochado de Almeida

1153 Zoomorfos na cerâmica da Idade do Ferro no NW Peninsular: inventário, cronologias e significado Nuno Oliveira / Cristina Seoane

1163 Vasos gregos em Portugal: diferentes maneiras de contar a história do intercâmbio cultural na Idade do Ferro

Daniela Ferreira

1175 Os exotica da necrópole da Idade do Ferro do Olival do Senhor dos Mártires (Alcácer do Sal) no seu contexto regional

Francisco B. Gomes

\section{Antiguidade Clássica e Tardia}

1191 O uso de madeira como combustível no sítio da Quinta de Crestelos (Baixo Sabor): da Idade do Ferro à Romanização Filipe Vaz / João Tereso / Sérgio Simões Pereira / José Sastre / Javier Larrazabal Galarza / Susana Cosme / José António Pereira / Israel Espi

1207 Cultivos de Época Romana no Baixo Sabor: continuidade em tempos de mudança? João Pedro Tereso / Sérgio Simões Pereira / Filipe Santos / Luís Seabra / Filipe Vaz

1221 A casa romana na Hispânia: aplicação dos modelos itálicos nas províncias ibéricas Fernanda Magalhães / Diego Machado / Manuela Martins

1235 As pinturas murais romanas da Rua General Sousa Machado, n. ${ }^{5}$ 1, Chaves José Carvalho

1243 Trás do Castelo (Vale de Mir, Pegarinhos, Alijó) - Uma exploração agrícola romana do Douro

Tony Silvino / Pedro Pereira

1255 A sequência de ocupação no quadrante sudeste de Bracara Augusta: as transformações de uma unidade doméstica Lara Fernandes / Manuela Martins

1263 Os Mosaicos com decoração geométrica e geométrico-vegetalista dos sítios arqueológicos da área do Conuentus Bracaraugustanus. Novas abordagens quanto à conservação, restauro, decoração e datação Maria de Fátima Abraços / Licínia Wrench

1277 “Casa Romana” do Castro de São Domingos (Cristelos, Lousada): Escavação, Estudo e Musealização Paulo André de P. Lemos

1291 A arqueobotânica no Castro de Guifões (Matosinhos, Noroeste de Portugal): O primeiro estudo carpológico

Luís Seabra / Andreia Arezes / Catarina Magalhães / José Varela / João Pedro Tereso 
1305 Um Horreum Augustano na Foz do Douro (Monte do Castelo de Gaia, Vila Nova de Gaia) Rui Ramos

1311 Ponderais romanos na Lusitânia: padrões, formas, materiais e contextos de utilização Diego Barrios Rodríguez

1323 Um almofariz centro-itálico na foz do Mondego

Marco Penajoia

1335 Estruturas romanas de Carnide - Lisboa Luísa Batalha / Mário Monteiro / Guilherme Cardoso

1347 O contexto funerário do sector da "necrópole NO" da Rua das Portas de S. Antão (Lisboa): o espaço, os artefactos, os indivíduos e a sua interconectividade na interpretação do passado Sílvia Loja, José Carlos Quaresma, Nelson Cabaço, Marina Lourenço, Sílvia Casimiro, Rodrigo Banha da Silva, Francisca Alves-Cardoso

${ }_{1361}$ Povoamento em época Romana na Amadora - resultados de um projeto pluridisciplinar Gisela Encarnação / Vanessa Dias

1371 A Arquitectura Residencial em Mirobriga (Santiago do Cacém): contributo a partir de um estudo de caso Filipe Sousa / Catarina Felício

${ }_{1385}$ O fim do ciclo. Saneamento e gestão de resíduos nos edifícios termais de Mirobriga (Santiago do Cacém)

Catarina Felício / Filipe Sousa

1399 Balsa, Topografia e Urbanismo de uma Cidade Portuária Vítor Silva Dias / João Pedro Bernardes / Celso Candeias / Cristina Tété Garcia

1413 No Largo das Mouras Velhas em Faro (2017): novas evidências da necrópole norte de Ossonoba e da sua ocupação medieval Ricardo Costeira da Silva / Paulo Botelho / Fernando Santos / Liliana Nunes

1429 Instrumentos de pesca recuperados numa fábrica de salga em Ossonoba (Faro) Inês Rasteiro / Ricardo Costeira da Silva / Paulo Botelho

1439 A Necrópole Romana do Eirô, Duas Igrejas (Penafiel): intervenção arqueológica de 2016 Laura Sousa / Teresa Soeiro

1457 Ritual, descarte ou afetividade? A presença de Canis lupus familiaris na Necrópole Noroeste de Olisipo (Lisboa)

Beatriz Calapez Santos / Sofia Simões Pereira / Rodrigo Banha da Silva / Sílvia Casimiro / Cleia Detry / Francisca Alves Cardoso

1467 Dinâmicas económicas em Bracara na Antiguidade Tardia Diego Machado / Manuela Martins / Fernanda Magalhães / Natália Botica

1479 Cerâmicas e Vidros da Antiguidade Tardia do Edifício sob a Igreja do Bom Jesus (Vila Nova de Gaia) Joaquim Filipe Ramos

1493 Novos contributos para a topografia histórica de Mértola no período romano e na Antiguidade Tardia Virgílio Lopes

\section{8. Época Medieval}

1511 Cerâmicas islâmicas no Garb setentrional "português": algumas evidências e incógnitas Constança dos Santos / Helena Catarino / Susana Gómez / Maria José Gonçalves / Isabel Inácio / Gonçalo Lopes / Jacinta Bugalhão / Sandra Cavaco / Jaquelina Covaneiro / Isabel Cristina Fernandes / Ana Sofia Gomes 
1525 Contributo para o conhecimento da cosmética islâmica, em Silves, durante a Idade Média Rosa Varela Gomes

1537 Yábura e o seu território - uma análise histórico-arqueológica de Évora entre os séculos VIII-XII José Rui Santos

1547 A encosta sul do Castelo de Palmela - resultados preliminares da escavação arqueológica Luís Filipe Pereira / Michelle Teixeira Santos

1559 A igreja de São Lourenço (Mouraria, Lisboa): um conjunto de silos e de cerâmica medieval islâmica

Andreia Filipa Moreira Rodrigues

1571 O registo material de movimentações populacionais no Médio Tejo, durante os séculos XII-XIII. Dois casos de "sunken featured buildings", nos concelhos de Cartaxo e Torres Novas Marco Liberato / Helena Santos / Nuno Santos

1585 O nordeste transmontano nos alvores da Idade média. Notas para reflexão Ana Maria da Costa Oliveira

1601 Sepulturas escavadas na rocha do Norte de Portugal e do Vale do Douro: primeiros resultados do Projecto SER-NPVD

Mário Jorge Barroca / César Guedes / Andreia Arezes / Ana Maria Oliveira

1619 "Portucalem Castrum Novum" entre o Mediterrâneo e o Atlântico: o estudo dos materiais cerâmicos alto-medievais do arqueossítio da rua de D. Hugo, nํ. 5 (Porto) João Luís Veloso

1627 A Alta Idade Média na fronteira de Lafões: notas preliminares sobre a Arqueologia no Concelho de Vouzela

Manuel Luís Real / Catarina Tente

1641 Um conjunto cerâmico medieval fora de portas: um breve testemunho aveirense Susana Temudo

${ }_{1651}$ Os Lóios do Porto: uma perspetiva integrada no panorama funerário da Baixa Idade Média à Época Moderna em meios urbanos em Portugal

Ana Lema Seabra

1659 O Caminho Português Interior de Santiago como eixo viário na Idade Média Pedro Azevedo

1665 Morfologia Urbana: Um exercício em torno do Castelo de Ourém André Donas-Botto / Jaqueline Pereira

1677 Intervenção arqueológica na Rua Marquês de Pombal/Largo do Espírito Santo (Bucelas, Loures)

Florbela Estêvão / Nathalie Antunes-Ferreira / Dário Ramos Neves / Inês Lisboa

1691 O Cemitério Medieval do Poço do Borratém e a espacialidade funerária na cidade de Lisboa Inês Belém / Vanessa Filipe / Vasco Noronha Vieira / Sónia Ferro / Rodrigo Banha da Silva

1705 Um Espaço Funerário Conventual do séc. XV em Lisboa: o caso do Convento de São Domingos da Cidade Sérgio Pedroso / Sílvia Casimiro / Rodrigo Banha da Silva / Francisca Alves Cardoso

\section{9. Época Moderna e Contemporânea}

1721 Arqueologia Moderna em Portugal: algumas reflexões críticas em torno da quantificação de conjuntos cerâmicos e suas inferências históricas e antropológicas Rodrigo Banha da Silva / André Bargão / Sara da Cruz Ferreira

1733 Faianças de dois contextos entre os finais do século XVI e XVIII do Palácio dos Condes de Penafiel, Lisboa

Martim Lopes / Tomás Mesquita 
1747 Um perfil de consumo do século XVIII na foz do Tejo: O caso do Mercado da Ribeira, Lisboa Sara da Cruz Ferreira / Rodrigo Banha da Silva / André Bargão

1761 Os Cachimbos dos Séculos XVII e XVIII do Palácio Mesquitela e Convento dos Inglesinhos (Lisboa)

Inês Simão / Marina Pinto / João Pimenta / Sara da Cruz Ferreira / André Bargão / Rodrigo Banha da Silva

1775 "Tomar os fumos da erua que chamão em Portugal erua sancta». Estudo de Cachimbos provenientes da Rua do Terreiro do Trigo, Lisboa

Miguel Martins de Sousa / José Pedro Henriques / Vanessa Galiza Filipe

1787 Cachimbos de Barro Caulínitico da Sé da Cidade Velha (República de Cabo Verde)

Rodrigo Banha da Silva / João Pimenta / Clementino Amaro

1801 Algumas considerações sobre espólio não cerâmico recuperado no Largo de Jesus (Lisboa) Carlos Boavida

1815 Adereços de vidro, dos séculos XVI-XVIII, procedentes do antigo Convento de Santana de Lisboa (anéis, braceletes e contas)

Joana Gonçalves / Rosa Varela Gomes / Mário Varela Gomes

1837 Da ostentação, luxo e poder à simplicidade do uso quotidiano: arqueologia e simbologia de joias e adornos da Idade Moderna Portuguesa Jéssica Iglésias

1849 Os amuletos em Portugal - dos objetos às superstições: o coral vermelho Alexandra Vieira

1865 Cerâmicas de Vila Franca de Xira nos séculos XV e XVI Eva Pires

1879 «Não passa por teu o que me pertence». Marcas de individualização associadas a faianças do Convento de Nossa Senhora de Aracoeli, Alcácer do Sal Catarina Parreira / Íris Fragoso / Miguel Martins de Sousa

1891 Cerâmica de Leiria: alguns focos de produção

Jaqueline Pereira / André Donas-Botto

1901 Os Fornos na Rua da Biquinha, em Óbidos Hugo Silva / Filipe Oliveira

1909 A casa de Pêro Fernandes, contador dos contos de D. Manuel I: o sítio arqueológico da Silha do Alferes, Seixal (século XVI) Mariana Nunes Ferreira

1921 O Alto da Vigia (Sintra) e a vigilância e defesa da costa Alexandre Gonçalves / Sandra Santos

1937 O contexto da torre sineira da Igreja de Santa Maria de Loures Paulo Calaveira / Martim Lopes

1949 A Necrópole do Hospital Militar do Castelo de São Jorge e as práticas funerárias na Lisboa de Época Moderna Susana Henriques / Liliana Matias de Carvalho / Ana Amarante / Sofia N. Wasterlain

1963 SAND - Sarilhos Grandes Entre dois Mundos: o adro da Igreja e a Paleobiologia dos ossos humanos recuperados

Paula Alves Pereira / Roger Lee Jesus / Bruno M. Magalhães

1975 Expansão urbana da vila de Cascais no século XVII e XVIII: a intervenção arqueológica na Rua da Vitória no 15 a 17

Tiago Pereira / Vanessa Filipe

1987 Novos dados para o conhecimento do Urbanismo de Faro em época Moderna Ana Rosa 
1995 Um exemplo de Arqueologia Urbana em Alcoutim: o Antigo Edifício dos CTT Marco Fernandes / Marta Dias / Alexandra Gradim / Virgílio Lopes / Susana Gómez Martínez

2007 Palácio dos Ferrazes (Rua das Flores/Rua da Vitória, Porto): a cocheira de Domingos Oliveira Maia

Francisco Raimundo

2021 As muitas vidas de um edifício urbano: História, Arqueologia e Antropologia no antigo Recreatório Paroquial de Penafiel Helena Bernardo / Jorge Sampaio / Marta Borges

2035 O convento de Nossa Senhora da Esperança de Ponta Delgada: o contributo da arqueologia para o conhecimento de um monumento identitário João Gonçalves Araújo / N’Zinga Oliveira

2047 Arqueologia na ilha do Corvo... em busca da capela de Nossa Senhora do Rosário Tânia Manuel Casimiro / José Luís Neto / Luís Borges / Pedro Parreira

2059 Perdidos à vista da Costa. Trabalhos arqueológicos subaquáticos na Barra do Tejo Jorge Freire / José Bettencourt / Augusto Salgado

2071 Arqueologia marítima em Cabo Verde: enquadramento e primeiros resultados do projecto CONCHA

José Bettencourt / Adilson Dias / Carlos Lima / Christelle Chouzenoux / Cristóvão Fonseca / Dúnia Pereira / Gonçalo Lopes / Inês Coelho / Jaylson Monteiro / José Lima / Maria Eugénia Alves / Patrícia Carvalho / Tiago Silva

2085 Trabalhos arqueológicos na Cidade Velha (Ribeira Grande de Santiago, Cabo Verde): reflexões sobre um projecto de investigação e divulgação patrimonial André Teixeira / Jaylson Monteiro / Mariana Mateus / Nireide Tavares / Cristovão Fonseca / Gonçalo C. Lopes / Joana Bento Torres / Dúnia Pereira / André Bargão / Aurélie Mayer / Bruno Zélie / Carlos Lima / Christelle Chouzenoux / Inês Henriques / Inês Pinto Coelho / José Lima / Patrícia Carvalho / Tiago Silva

2103 A antiga fortificação de Quelba / Khor Kalba (E.A.U.). Resultados de quatro campanhas de escavações, problemáticas e perspectivas futuras Rui Carita / Rosa Varela Gomes / Mário Varela Gomes / Kamyar Kamyad

2123 Colónias para homens novos: arqueologia da colonização agrária fascista no noroeste ibérico Xurxo Ayán Vila / José Mạ . Señorán Martín 


\title{
A ALTA IDADE MÉDIA NA FRONTEIRA DE LAFÕES: NOTAS PRELIMINARES SOBRE A ARQUEOLOGIA NO CONCELHO DE VOUZELA
}

\author{
Manuel Luís Real ${ }^{1}$, Catarina Tente ${ }^{2}$
}

\begin{abstract}
RESUMO
Desde a proto-história que o território de Lafões foi submetido a uma intensa ocupação humana, com o intuito de explorar as suas riquezas minerais. Durante a Alta Idade Média foi uma zona chave na região centro de Portugal. Aqui encontramos indícios (escritos e arqueológicos) para a presença de populações locais cristãs, às quais se vieram juntar membros da nobreza galaico-asturiana, por eventual acordo estabelecido entre os sécs. IX e X. Após quase uma centúria de domínio político cristão, a região de Lafões ficou temporariamente na posse muçulmana, para ser finalmente resgatada quando se deu a reconquista de Viseu (1058) e de Coimbra (1064). Nessa altura, a fortificação da Senhora do Castelo (Vouzela), conhecida na documentação, mas só agora revelada arqueologicamente, já desempenharia funções estratégicas de relevância.
\end{abstract}

Palavras-chave: Lafões, Vouzela, Ocupação de montanha, Territórios medievais.

\begin{abstract}
The Lafões territory was subjected to an intense human occupation since Protohistoric times, focused on the exploitatian of its mineral wealth. In the Early Middle Ages it was a kea-area where written and archaeological evidence shows its importance for local Christian populations and to recently-established Galician-Asturian lords. After almost a century of Christian rule, the Lafões region was temporarily back in Muslim hands, only to be finally regained when Viseu and Coimbra were reconquered (in 1058 and 1064, respectively). At that time, the fort that has now been revealed archaeologically on Monte da Senhora do Castelo (Mount of Our Lady of the Castle) in Vouzela would have already a relevant strategic functions.
\end{abstract}

Keywords: Vouzela, Lafões, Mountain occupations, Medieval territories.

\section{INTRODUÇÃO}

Nos últimos quatro anos foram realizados vários trabalhos de inventário, prospeção e escavação arqueológica na região de Lafões-Vouzela. Esta investigação decorreu no âmbito do PIPA (2016-2019) Estudo do Património Histórico-Arqueológico de Vouzela (LAFÕES), que visava a sistematização da informação histórico-arqueológica e a obtenção de novos dados sobre o património arqueológico existente no território do atual concelho de Vouzela. Este conhecimento foi bastante ampliado, em particular após os incêndios de outubro de 2017, momento que determinou um investimento sem precedentes na intensidade da prospeção sistemática das áreas ardidas. $\mathrm{O}$ projeto contou com o apoio logístico e financeiro da autarquia, a qual disponibilizou igualmente alguns dos seus colaboradores, para reforçar a equipa de investigação.

No plano metodológico, a investigação orientou-se em quatro direções: 1 - Levantamento documental e toponímico; 2 - Prospeção arqueológica e análise espacial; 3 - Estudo de espólios das escavações antigas; 4 - Escavações arqueológicas. Merece especial

1. CITCEM-UP; IEM - NOVA FCSH; manuelluisreal@gmail.com

2. IEM - NOVA FCSH, Av. de Berna, 26C, 1069-o61 Lisboa; catarina.tente@gmail.com 
referência o registo sistemático da microtoponímia, a partir do cadastro de propriedades da Repartição das Finanças. Esta tarefa, que ficou a cargo de um investigador do Município3 ${ }^{3}$, veio a ampliar largamente as pistas para localização de novos sítios arqueológicos. O intensivo trabalho de prospeção levado a efeito permitiu assim identificar muitos locais até então desconhecidos e reconhecer melhor outros que estavam já referenciados na bibliografia sobre o património concelhio ${ }^{4}$.

Os dados obtidos ao longo do projeto permitem muitas abordagens à ocupação daquele território. O que nos ocupa neste artigo são algumas considerações que podem já ser avançadas no que se refere à ocupação alto medieval. Como já largamente abordado, a região de Lafões foi na Alta Idade Média um território relevante e protagonista de alguns episódios relacionados com avanços e recuos da fronteira entre cristãos e muçulmanos. Mas também foi palco de estratégias sociopolíticas de elites locais e supralocais. Sabemo-lo devido à documentação escrita que se conservou até aos dias de hoje.

Embora, como se referiu, o projeto tivesse objetivos mais abrangentes, pode considerar-se que, no que concerne ao período medieval, logrou atingir avanços significativos para o conhecimento da região de Lafões entre os séculos VIII e XI5.

\section{O PERÍODO DAS MONARQUIAS SUEVA E VISIGODA}

São inúmeros os locais com indícios de romanização, embora deles estejam sistematicamente ausentes os objetos de luxo ou de importação, bem como ocupações rurais mais suntuosas. Não há dúvida

\footnotetext{
3. A pesquisa ficou a cargo de Daniel de Melo Branco, que nas tradicionais 12 freguesias do concelho registou cerca de 17.850 ocorrências. Alguns topónimos aparecem repetidas vezes, até sob designação variável, mas a riqueza informativa coligida foi preciosa para as tarefas de prospeção.

4. Entre a bibliografia publicada são de salientar o trabalho pioneiro de A. Amorim Girão, sobre as Antiguidades Pre-históricas de Lafões, assim como a Carta Arqueológica do Concelho de Vouzela, da autoria de Jorge Adolfo de M. Marques.

5. Para conhecimento mais detalhado sobre os temas aqui tratados poderão consultar-se as comunicações às I Jornadas de Arqueologia de Vouzela-Lafões, que se realizaram a 14-16 de Novembro de 2019 e cujas atas estão em vias de publicação.
}

que o território foi submetido a uma intensa ocupação romana, indubitavelmente com o intuito da exploração das riquezas mineiras da região. Aliás, estas haviam também sido responsáveis pela intensa ocupação pré-romana da região, que tão eloquentemente se expressa nos diversos castros de grande dimensão ali existentes e nas inúmeras e densas necrópoles de cistas que aqui se identificaram nos últimos anos (Carvalho, Carvalho, 2018). Os recursos minerais foram o motor para ocupação intensiva deste território desde a Idade do Bronze e terão sido estes mesmos recursos que suportaram a construção das emblemáticas termas de São Pedro do Sul. Os principais vestígios romanos e tardo-romanos estão fundamentalmente relacionados com a exploração dos recursos mineiros. São disso exemplo o sítio de Carvalhal do Estanho, onde também se reconheceu uma necrópole tardia, ou o lugar de Fataunços, situado junto a uma das principais vias de comunicação e na periferia de outra importante zona mineira, na vertente ocidental do monte da Senhora do Castelo (Figura 1). A exploração dos recursos e a posição de fronteira deste território terá sido responsável pela construção de inúmeras vias (muitas delas calçadas) que ligariam o litoral ao interior, desde Talabriga a Vissaium, quer através do vale do Vouga, quer atravessando a Serra do Caramulo. O controle romano da região deve ter-se centrado junto às vizinhas Termas Romanas (situadas no limite do atual concelho de S. Pedro do Sul), onde estanciaria a elite militar e administrativa.

Para o período do fim do Império na região, pouco se pode adiantar. É provável que se tenha continuado a ocupar espaços já anteriormente habitados, tal como ocorreu em Fataunços e no Carvalhal do Estanho. Em ambos os sítios estão documentadas necrópoles de inumação que usaram materiais de tradição romana, como tegulae. Na zona do Areal/ Corgo (Fataunços), foram igualmente reconhecidas sepulturas escavadas na rocha (Marques, 1999), cuja cronologia poderá recuar até ao século VI.

Apesar dos parcos indícios materiais, certamente que a região não terá sido despovoada após o século V. Assim o faz pensar a proximidade de Viseu, que assume protagonismo político na época, ao elevar-se a sede episcopal durante a sexta centúria. Apesar do controle que os bispos exerceriam nos territórios rurais ser assimétrico e depender, muitas das vezes, dos laços que conseguiam estabelecer com as elites locais (Tente, 2016), a proximidade geográfica de La- 
fões a Viseu e a presença das termas (que certamente não terão cessado de funcionar e continuariam a ser um pólo de atração importante para a aristocracia da época) devem ter colocado Lafões no mapa de interesses diretos das próprias elites viseenses. Não será de descartar a hipótese da continuidade de ocupação dos antigos castros romanizados, nomeadamente os de Ribamá (Queirã) e da Senhora do Castelo (Vouzela), onde se identificaram sepulturas escavadas na rocha, que podem ter tido origem no período das monarquias suevo-visigoda. Muito poderíamos discutir sobre a cronologia das sepulturas escavadas na rocha, cuja janela temporal para a sua utilização é demasiado alargada (século VI - XII). Todavia, Lafões constitui-se como um caso interessante, pois são muito escassas as sepulturas aqui identificadas, o que contrasta com a restante região da Beira Alta. Efetivamente, de Viseu à Guarda, passando por regiões de vale e zonas serranas, é muito comum este tipo de vestígios e, quando associados a outros dados arqueológicos, eles remetem-nos para cronologias balizadas entre o século IX e o XI. Ocorre que em Vouzela/Lafões, tal como se irá expor, é neste período que se ergue uma série de templos cristãos, circunstância que parece ser responsável pela ausência destas soluções funerárias rupestres, que resultam em larga maioria de opções de cariz familiar (Tente, 2017). É possível, ainda que não comprovável, que algumas das escassas sepulturas escavadas na rocha de Vouzela possam ter sido construídas num momento anterior ao século IX, quando as elites locais controlariam já as comunidades e os seus hábitos religioso/funerários.

\section{DO SÉCULO VIII AO SÉCULO XII}

Com a invasão islâmica, este território passou a apresentar características muito peculiares, por se situar num espaço que não seria controlado efetivamente, nem pelo norte cristão-asturiano, nem pelo sul islâmico. É possível que em algum momento, durante o século VIII, as elites locais tenham estabelecido um pacto de submissão com o poder muçulmano. Nestes pactos os cristãos mantinham a liberdade de culto e era-lhes conferido o direito de propriedade, devendo, em contrapartida, respeitar o Islão e pagar imposto próprio. Esta circunstância pode eventualmente explicar o desenvolvimento de uma comunidade moçárabe em Lafões, da qual, inclusive, nos chegou testemunho através de fonte árabe, relativa a certa investida do cadi de Sevilha, por volta de 1026-1030 (Aillet, 2005).

É significativo notar que o topónimo “Loumão”, povoação atual designada como Noumam nas Inquirições de 1258 , tem uma origem árabe, o que pode remeter para esta comunidade arabizada que habitaria na região de Vouzela. O lugar de Loumão fica, precisamente, junto ao núcleo mineiro mais rico do concelho, e aí identificou-se a ruína de uma torre, cuja construção deverá situar-se entre os séculos. IX-X (Figura 2), se a compararmos com o aparelho ostentado na coeva capela de S. Martinho, integrada no complexo das termas de S. Pedro do Sul.

A documentação e alguns achados arqueológicos mostram uma intensa ocupação, que se expressa no número de edifícios religiosos que terão sido erguidos, nomeadamente a partir do século X. Esta invulgar densidade de templos contrasta com a generalidade da região situada entre o Douro e o Mondego. Dos primeiros templos temos aparentemente vestígios na fase mais antiga da capela de S. Martinho de Alcofra (Fig. 9, fase I), que então poderia ter sido apenas um diminuto oratório. Talvez mais importante e também muito antigo seria o templo original de Carvalhal de Estanho, igualmente dedicado a S. Martinho. A igreja atual é de construção moderna, mas situa-se junto ao núcleo romano das minas da Bejanca e estava rodeada pela maior necrópole conhecida, até ao momento, no concelho de Vouzela. $\mathrm{O}$ orago tem fortes possibilidades de ser muito arcaico e, segundo testemunhos recolhidos, tal cemitério continha campas em tegulae, de presumível tipologia romana, sarcófagos em granito e sepulturas abertas na rocha.

Tendo em conta um arco cronológico mais amplo, sensivelmente entre a época tardo-romana e o século XI, só na área concelhia de Vouzela - correspondente a uns exíguos $194 \mathrm{Km}^{2}$ - por informação documental ou através de vestígios materiais, identificaram-se com segurança cerca de uma dúzia de templos e há indícios de mais alguns (Figura. 3). Do ponto de vista arqueológico, encontraram-se testemunhos concretos em S. Martinho de Alcofra (na capela mor e primeira fase de construção da nave - Figura 9), em S $\mathbf{a}$ Maria de Figueiredo das Donas (fustes de coluna, pedras almofadadas, fragmento de ara e inscrição alto medieval - Figura 8), em S $\mathrm{S}^{\underline{a}}$ Marinha de Paços de Vilharigues (distante da atual sede paroquial, mas com o mesmo orago - existindo fragmento de muro original, silhares com desbaste dos antigos 
almofadados, cruz gravada e restos de tegulae nas imediações), em S. Miguel de Felgosa (no Passal, em Fataúnços - fig. 10, tendo-se identificado um cunhal com pedras almofadadas, o saimel de arco em ferradura, estelas sepulcrais e fragmentos de telha curva, antiga e moderna) e em S. Miguel de Queirã (elementos de coluna, medidos pelo palmo craveiro e atribuíveis à primitiva igreja).

Tal como já abordado, há uma percentagem bastante reduzida de sepulturas escavadas na rocha: para além dos casos já citados, apenas se documentam o par de sepulturas em Lamas (Paços de Vilharigues), a sepultura antropomórfica do Lameirão de S. Domingos (Ventosa) e a campa rupestre do Castro da Ribamá (Figura 4). Como atrás se expôs, é possível que estas sepulturas tenham sido construídas entre os séculos VI e VIII, pelo que não se relacionam com a nova realidade, quando se terá intensificado a construção de edifícios religiosos na região. Efetivamente, após o século IX tudo indica que o território passou a estar enquadrado por uma densa malha de templos. A relativamente rápida cobertura religiosa, mediante a criação vários centros de acolhimento e serviço eclesiástico, fez com que os fiéis neles procurassem, muito precocemente, um lugar para enterrar os seus mortos. A maior parte destes lugares estão por investigar arqueologicamente, mas conhece-se o aparecimento de campas e/ou estelas sepulcrais - neste caso, um pouco mais tardias - na matriz de Vouzela e em algumas outras sedes de freguesia (Alcofra, Campia, Passal/Fataúnços). Quanto às sepulturas antropomórficas da Senhora do Castelo, encostadas à cerca do povoado alto medieval, no seu lado exterior ${ }^{6}$, elas poderiam ter justificação lógica pela sua proximidade ao aldeamento relacionado com o castelo ali existente, mas é igualmente provável que possam ser anteriores à construção do castelo. Seriam assim mais antigas e integrar-se-iam na cronologia avançada para as demais sepulturas escavadas na rocha identificadas neste concelho, isto é, entre o século VI e o IX. Teriam sido erguidas junto a um local que já anteriormente estava ocupado (desde a Idade do Bronze) numa situação muito semelhante à que se detetou no castro de Ribamá e que aqui já foi referido. A capela da Senhora

6. Tal cerca desapareceu neste local, mas o seu alinhamento pode reconstituir-se tendo em conta o traçado geral do circuito, percetível através da topografia do terreno e por trechos do próprio muro. do Castelo, refeita várias vezes, foi erguida no cimo do monte apenas quando a torre castrense deixou de desempenhar funções militares, pelo que, na hipótese de haver um anterior templo dedicado a Santa Maria, este deveria ter sido erguido nas imediações das sepulturas.

O exemplo da Senhora do Castelo remete-nos para um outro problema, muito debatido em estudos sobre o povoamento na Alta Idade Média. Costuma dar-se especial ênfase ao encastelamento, cuja origem se prolonga no tempo, mas teve particular expressão ao longo do século XI. A prospeção arqueológica revelou que no monte da Senhora do Castelo, em Vouzela, surgiu um importante castro da Idade do Bronze, o qual veio a ser abandonado na época romana, provavelmente quando aí se intensificaram os trabalhos de mineração. Na Alta Idade Média o cimo do monte voltou a ter ocupação. Recentemente foi identificado um dos muros da torre medieva, em torno da qual se parece estender um pequeno povoado. No atual estado de conhecimentos não podemos aferir se a origem de tal povoado é anterior à torre ou lhe sucedeu. Só escavações arqueológicas poderão, eventualmente, permitir chegar a uma conclusão mais segura a esse respeito. Todavia, daquilo que se sabe sobre o processo histórico da região, emerge uma interessante problemática a respeito do paulatino desenvolvimento do sistema de governança e defesa deste território.

\section{LAFÕES NO QUADRO DA EXPANSÃO TERRITORIAL ASTURIANA NO OCIDENTE PENINSULAR}

É hoje praticamente adquirido que no vale do Vouga, em finais do século IX, se veio a refugiar o príncipe asturiano Bermudo Ordonhes, na sequência de uma frustrada revolta contra seu irmão, o rei Afonso Magno. A região de Viseu pode ter-se transformado, nesta época, em zona de abrigo de alguns nobres descontentes e insubmissos frente à corte de Oviedo, como Diogo Fernandes, alguns descendentes dos presores de Tude e de Portucale e, supostamente (embora isso seja menos seguro) o conde Odoário, outro irmão do monarca, que foi presor de Flavias e poderá ter dominado em Viseum. Ora, a instalação de gente tão insigne vinda do norte galaico-asturiano, para ser pacífica, não pode deixar de ter sido precedida de contactos prévios e uma negociação com elites locais (Real, 2013: 209-211). Na verdade, nos 
territórios de fronteira vivia-se com relativa autonomia, o que terá favorecido a emergência de uma multiplicidade de pequenos poderes. Para as vizinhanças do atual concelho de Vouzela há indícios de alguns centros de poder secundários, esporadicamente referidos em documentação posterior, mas que devem assentar numa tradição mais antiga. É o caso do chamado "territorio Centum Cortes" (DC 61 e 660) e do "territorio Sancte Cruce" (DC 672), o primeiro documentado logo no século X e o segundo um pouco mais tardiamente, mas ambos absorvidos entretanto pela undecentista Terra de Lafões. É bem possível que a fortificação conhecida como "mons Aguto" ou "mons Castro Alafoei", tenha sido erguida para controlar o território, mostrar e representar o poder das gentes que o dominavam e defende-lo das ameaças externas a que ele estava sujeito. A primeira referência documental ao castelo de Lafões data do ano 1019, numa carta de venda a Fromarigo Viegas, da villa de Ferreiros, junto à margem direita do Vouga e mesmo defronte a Vouzela ("castro alahoueines” - DC 243) $)^{7}$. Embora não saibamos, ao certo, quando o monte foi reocupado militarmente, é possível que tal possa ter sucedido quando os habitantes locais começaram a sentir necessidade de reforçar a sua segurança ou, em alternativa, a partir do momento em que aceitaram que o citado grupo de dissidentes galaico-asturianos se instalasse nesta região. Como veremos a seguir, a importância estratégica da fortificação terá aumentado durante o reinado de Afonso V de Leon, quando a região de Viseu começou a ser, de novo, assediada por forças cristãs. E só assim se explica que, em dois documentos de 1030, apareça já uma referência ao "territorium alahoueines" ou "territorium alahobeines" (DC $268 \mathrm{e}$ AUC, Pergaminhos, IV-3 $3^{\mathrm{a}}$, Gav. 29, no 1$)^{8}$. Todavia, é possível que só se tenha transformado em cabeça de Terra na segunda metade do século XI, a partir da reconquista das cidades de Viseu e Coimbra por Fernando Magno. Este monarca rapidamente perce-

7. Tem sido também invocado o DC 19o, supostamente datado do ano 1002, porque fala do "territorio alaphoen”, um corónimo que supõe já a existência do castelo do mesmo nome. Todavia a data foi corrigida para 1102, na recente edição do Livro Preto da Sé de Coimbra (LP 495).

8. Agradecemos ao Dr. Daniel Melo o conhecimento da existência deste último documento e, ao Arquivo da Universidade de Coimbra (AUC), as facilidades que nos deu para a consulta do mesmo. beu que, para controlar as áreas conquistadas, tinha de afastar a alta aristocracia tradicional do exercício do poder político-militar. É neste contexto que o governo do território entre Coimbra e Arouca é entregue a um $d u x$ de confiança régia, ao qual ficavam submetidos os chefes militares ou funcionários encarregados da tenência das Terras.

Com o decorrer do tempo, como se viu, a área geográfica dominada por este castelo passou a ser conhecida por "territorio alahueines", expressão com algumas variantes formais. É consensual que este designativo deriva de al-`ahwân, nome que em árabe se referia ao castelo dos "dois irmãos", assim denominado pelo par de outeiros que coroam o monte da Senhora do Castelo. Esta designação tem paralelismo em outros topónimos castrenses de raiz latina, mas com o mesmo significado: por exemplo, nos castelos beirãos de Germanelo e Jarmelo.

A fortificação vouzelense seria de planta quase quadrangular e estava assente numa amplo tor granítico. Durante a vigência deste projeto foi posto a descoberto um muro em cuja base se perceciona ainda uma estrutura arruinada que remonta à fase mais antiga do castelo medieval. Esta base, posteriormente, deu lugar à radical reconstrução da própria torre do castelo (Figura 5). É possível que a ruína da primeira fortificação se possa ter devido a confrontos decorrentes da desestabilização regional que ocorreu no contexto das campanhas militares de Almançor ou, mais provavelmente, na já referida investida do cadi de Sevilha e quando a região foi assolada por várias incursões das forças em contenda. $\mathrm{O}$ ataque sevilhano ao castelo de Lafões, com o cativeiro de cerca de 300 cavaleiros, poderá ter ocorrido entre 1026-1030 (Aillet, 2010: 300). Este episódio, relatado por fonte muçulmana, tem dado origem a várias interpretações sobre a respetiva data e quanto à origem de uma parte de população cristã, que falava correntemente o árabe. Assim, o debate tem incidido mais sobre aspetos concretos de tal acontecimento, do que acerca da sua relevância no contexto do plano leonês para recuperar as cidades fronteiriças de Viseu e Coimbra. As condições para desencadear uma operação militar de tão ampla envergadura, por parte do rei Afonso V, só se começaram a proporcionar a partir de 1016-1023, ou seja, depois de afastados alguns perigos internos para a monarquia e interrompidas as ameaças vindas do exterior, em consequência da desintegração política do califado (Real, 2018: 326-327). A base territo- 
rial da estratégia leonesa, neste momento, passou a ser a Terra de Santa Maria e o vale do Vouga, de conflito com partidários do poder califal, mas que sempre mantivera uma forte presença cristã e cuja jurisdição, por delegação do rei leonês, passou a estar a cargo do conde Mendo Lucídes (Mattoso, 1981: 110). Daí terão partido os principais ataques ${ }^{9}$, dando origem a um período de grande instabilidade regional, expressa na documentação coeva, que fala do resgate de cativos, da fuga do abade da Vacariça para o mosteiro de Leça, a norte do Douro, e do conflito contra os próprios conterrâneos que, no passado, se tinham aliado a Almançor e agora ocupavam posições de destaque. Nesta primeira fase, a frente mais avançada terá ficado a cargo de dois irmãos da casa de Marnel, linhagem descendente do conde Ero Fernandes e cujo castelo senhorial ocupava uma posição estratégica primordial no baixo Vouga, controlando a antiga estrada romana que ligava Portucale a Emínio e a via secundária que daí seguia para Viseu. Tais irmãos eram filhos de Egas Eris Iala e atuariam, decerto também por delegação régia, sob a autoridade do referido conde Mendo Lucídes ${ }^{10}$. Ao primogénito, Gonçalo Viegas, coube governar Montemor, cujo castelo fora tomado cerca de 1017, como etapa preliminar para o assalto a Coimbra (In era $M^{\underline{\underline{a}}} L^{\underline{\underline{a}}} V^{\underline{\underline{u}}}$ si ganaui domno iben gundisaluo iben egas... in diebus domno adefonso rex quando sedia in monte maiore de manu ille rex - DC 549). Embora as fontes documentais não sejam tão explícitas, terá cabido a seu irmão, Fromarigo Viegas, uma iniciativa

9. É possível que também tenha havido um envolvimento de Viseu a partir do sul, tal como parece comprovar-se pela existência de uma epígrafe cristã do ano 1018, em Vila Maior (Sabugal), onde aparece o nome de Osorio Teles, primo do conde Mendo Lucídes, e tal como este, neto de Alvito Nunes e Múnia Dias. Encontram-se ambos ligados ao clã de Lafões, donde alguns dos seus membros partiram para colonizar o vale superior do Mondego (Real, 2018: 325 e fig. 11).

10. O conde Mendo Lucídes deve ser filho de Lucídio Alvites, segundo José Mattoso, sendo assim descendente em $4^{\circ}$ grau do presor de Portucale, Vímara Peres. Ele está já ao lado de Afonso V em 1014 (DC 223) e num documento de 1019 fala-se da conquista da praça de Montemor, que anteriormente se encontrava a cargo do governador nomeado pelos muçulmanos, Froila Gonçalves, "sed superualiauit eum menendus lucidi” (LP 134). O conde Mendo Lucídes deve ser entendido, aqui, apenas como o representante do rei, já que o castelo havia sido tomado dois anos antes por Gonçalo Viegas de Marnel, que era quem exerceria funções militares no terreno. paralela sobre o castelo de Lafões ${ }^{11}$. Dois anos mais tarde, ele estava já a adquirir uma propriedade em Vouzela, no sopé do monte da Senhora do Castelo $(D C 243)^{12}$ e reaparecerá em dois documentos de 1030, num deles com funções de tenência territorial (DC 268) e noutro a receber incomuniação de uma herdade no vizinho lugar de Iben Ordonis ${ }^{13}$. Neste intervalo de tempo é que decorreu o fatídico cerco à cidade de Viseu (1028), na sequência do qual o rei Afonso $\mathrm{V}$ viria a falecer, atingido por uma seta. E em data incerta, mas seguramente numa missão de auxílio à quase isolada guarnição militar de Viseu, dá-se o assalto ao ameaçador castelo de Lafões, por tropas sevilhanas comandadas pelo cadi Abû al-Qâsim, de acordo com alguns analistas, ou pelo segundo rei da taifa, al-Mu'tadid, no dizer de fonte árabe. É bem possível que a morte do monarca e, sobretudo, esta celebrada vitória muçulmana em Vouzela tenham conseguido suster, por algumas décadas, a queda de Viseu. A reconquista da cidade só sucederá no tempo de Fernando Magno, através de um envolvimento militar de algum modo inspirado na estratégia montada, já nos anos 20 , por Afonso $\mathrm{V}$ de Leon. Sendo certo que Viseu conseguiu resistir, a região de Lafões poderá ter continuado como linha avançada das forças cristãs, cada vez mais pressionantes, tal como sucedeu em Montemor relativamente a Coimbra ${ }^{14}$.

Como é óbvio, o controlo de um território não se podia restringir a apenas um ponto fortificado. Tem

\footnotetext{
11. Deve-se a A. de Almeida Fernandes a chamada de atenção para a quase simultaneidade das ações militares sobre os castelos de Montemor e Lafões, que confirmamos terem sido dirigidas separadamente
}

por dois membros da casa de Marnel, irmãos entre si (Fernandes, 1972: 201-205).

12. Em Ferreiros, junto à quinta de Valgode e na margem direita do Vouga, onde brotam também águas termais.

13. Trata-se de Bordonhos, uma villa aristocrata em que terá vivido exilado o príncipe asturiano Bermudo Ordonhes, irmão de Afonso Magno (AUC, Pergaminhos, IV-3 $3^{\underline{a}}$, Gav. $29, \mathrm{n}^{\circ}{ }^{1}$ ).

14. Montemor será reconquistada em 1034 por Gonçalo Trastamires, da Maia. Não deve ser por acaso que se repete novo paralelismo histórico com a tenência do castelo de Lafões, cuja liderança virá a ser entregue a outro prócere da Maia, Piniolo Garcia. A mudança política pode ter-se iniciado com a crise instaurada nos anos finais do reinado de Bermudo III e a subida ao trono de Fernando Magno, após a batalha de Tamarón. 
vindo a ser detetada uma complexa rede defensiva que incluía outros castelos, com função mais restrita, e uma série de atalaias e fachos de comunicação. Uma boa parte do sistema extravasa, naturalmente, para fora da área do município de Vouzela. Mesmo assim, dentro do território concelhio existe uma variedade tipológica de postos miltares, que é bastante representativa das múltiplas funções e dos distintos níveis de atuação no âmbito do sistema: Castêlo (castelo roqueiro que defendia o vale de Alcofra e controlava itinerários alternativos que, a partir de Viseu e de Besteiros, se dirigiam para Vouzela ou para o litoral - Figura 6; dado a conhecer em Marques, 1999: 39); Pena da Penoita ou Outeiro dos Mouros (elevação roqueira com importante posição estratégica, pela sua ampla visibilidade regional, superior à Senhora do Castelo); Atalaia (posto de controlo da antiga calçada romana, junto à Ponte Pedrinha); Esculca (ponto de vigilância, ao serviço de uma pequena instalação rural de altitude, nos Lameiros Tapados); Candeeira (possíveis lugares onde se produziam sinais luminosos). Todavia, para a maior parte dos locais não possuímos dados arqueológicos para a sua cronologia. O povoamento do território concelhio deveria, então, apresentar já uma notável diversidade. Quase todas as sedes de freguesia estão referenciadas documentalmente desde cedo, mas raramente fornecem vestígios materiais de ocupação antiga, fruto do sucessivo desgaste causado pelo uso permanente do espaço. Uma das características mais interessantes deste território e que, uma vez mais, contrasta com a restante região beirã, é o facto da rede de aldeias (muitas delas sobreviventes até hoje) ter sido definida num momento muito recuado da Idade Média. Não é possível precisar a cronologia para o início da constituição desta rede de povoamento, precisamente porque os vestígios jazem sob as atuais povoações. Identificaram-se também vários povoados abandonados, como o do Pobral (Ventosa), de origem seguramente remota, mas cuja amplidão, estado ruinoso e densidade florestal dificultam o respetivo estudo. O projeto permitiu ainda a identificação de um conjunto de sítios rurais bastante promissores para a investigação arqueológica altomedieval. O primeiro a ser arqueologicamente intervencionado situa-se nos Lameiros Tapados, no limite de Ventosa com Paços de Vilharigues (Figura 7). Trata-se de um sítio de montanha, mas que ocupa uma rechã protegida por um tor granítico dominante e onde há facilidade de acesso a uma fonte de água. O sítio foi reconhecido na sequência dos incêndios de 2017. Apesar de não se identificarem materiais arqueológicos à superfície, eram visíveis uns alinhamentos de muros de duplo paramento, os quais levaram a que a intervenção fosse ali efetuada. A primeira campanha de escavações revelou cerca de uma meia dúzia de construções pétreas de planta alongada (sub-retangulares), que apresentam apenas uma entrada, um espaço de fogueira no seu interior e áreas de trabalho (aqui foram identificados diversos elementos de dormentes de vai-vem, assim como moventes em granito). É possível que se tratem de construções de carácter sazonal, erguidas e em uso entre os séculos X/XI, que podem ter sido utilizadas por várias famílias durante o Verão, para o aproveitamento dos pastos de altitude. A investigação ainda está no início, pelo que é prematuro avançar com mais interpretações.

A existência de elites terratenentes parece ser, desde muito cedo, uma das marcas caracterizadoras da região de Lafões. O mais significativo indício disto é a migração de um príncipe asturiano - Bermudo Ordonhes - que se veio a instalar na villa Iben Ordonis (Bordonhos - c. São Pedro do Sul), quer dizer, na herdade do filho do [rei] Ordonho. Muito possivelmente foi ele o fundador da capela de S. Martinho, anexa ao Banho de Lafões. E na outra margem do Vouga encontrava-se a villa ou paço de Moçâmedes (c. Vouzela), pertencente a Diogo Fernandes e Onega. Aí nasceu a futura condessa Mumadona e foi criado, na infância, o célebre rei Ramiro, seu irmão de leite (Real, 2013: 211-215). Em redor desta casa senhorial gravitaram também dois descendentes do conde Afonso Betotes e um neto de Vímara Peres, os quais vieram a casar com as filhas de Diogo e Onega. Mas haveria mais gente nobilitada, como parece poder concluir-se do precoce surgimento do topónimo $\mathrm{Pa}$ ços (de Vilharigues), cujo dono - hoje desconhecido - deve ter sido o patrono da vizinha igreja pré-românica de $S^{a}$ Marinha, já desaparecida, mas da qual ainda restam vestígios no local, como se referiu acima. Após a conquista de Almançor e com as lutas pela recuperação cristã do território, no tempo de Fernando Magno, as linhagens tradicionais viram-se ultrapassadas por algumas famílias de infanções que souberam aproveitar o momento para se guindarem socialmente, aproximando-se da corte e enriquecendo o seu património. A sua origem encontra-se pouco esclarecida, por vezes, mas provavelmente elas emergem de desconhecidas elites da região ou pertencem a ramos bastante colaterais da antiga 
nobreza terratenente. Estão neste caso, bem documentados em Lafões, homens como Cid David, Cid Aires ou João Gosendes (Ventura, 1985). Mas existirão outros, cuja memória quase se perdeu, como aquele Auriasu Crescones, que uma epígrafe datável do século XI, encontrada durante no âmbito do atual Projeto, nos ensina que fecit a igreja de $\mathrm{S}^{\underline{a}}$ Maria de Figueiredo das Donas (Figura 8). Os dois primeiros estão ligados à fundação das cavalarias vilãs de Vouzela e de Alcofra, estruturas paramilitares criadas a par dos progressos da conquista, com o intuito de reforçar os meios de defesa fronteiriça e de auxiliar o rei quando este ia em fossado sobre terras inimigas. Os chefes de tais elites irão tornar-se patronos de novos mosteiros, fundados pela respetiva linhagem, como aconteceu nos de Santa Maria de Vouzela ou de São Pedro do Sul. A Cid Aires poderá ser atribuída também a fase proto-românica da igreja de S. Martinho de Alcofra (Figura 9, fase II). Esta última, tal como os mosteiros acima referidos, a igreja de $\mathrm{S}$. Miguel de Folgosa, sobranceira à villa de Fataúnços (Figura 10), e outras casas religiosas cedo nomeadas na documentação, virão a ser protagonistas no precoce processo de paroquialização da Terra de Lafões. Abre-se assim um novo ciclo na gestão do território, que acompanha a reorganização de poderes, coeva da instauração da Monarquia por iniciativa do rei D. Afonso Henriques, que colocará homens da sua confiança à frente da Terra de Lafões e nela facilitará a implantação do mosteiro de $S^{a}$ Cruz de Coimbra.

Uma das características mais notórias deste território é a intensa exploração mineira, que foi amiúde responsável, não só pela acentuada densidade ocupacional da região, mas também pelo revolvimento de solos que alterou os contextos arqueológicos, quando não mesmo os destruiu. Não se conseguiu ainda comprovar arqueologicamente a continuidade das explorações de estanho e ouro, que desde a Proto-História caracterizaram a vida económica da região. Todavia, a circunstância de ter existido uma torre senhorial em Noumam (Loumão), situada em plena zona mineira e propriedade de um potente, pode indiciar que então ainda pudessem estar em exploração recursos mineiros. Tal hipótese não é de descurar, mesmo que seja admitida a perda de importância da extração de minério nesta época. Não podendo ser ainda comprovada esta atividade no período Alto Medieval, fica a certeza de a mesma ter sobrevivido em Lafões em épocas mais tardias, numa clara continuidade de aproveitamento dos recursos que o território dispunha para oferecer aos seus habitantes.

\section{FONTES UTILIZADAS}

DC - Portugaliae Monumenta Historica: Diplomatae et Chartae. Lisboa: Academia das Ciências, 1867 e ss.

LP - Livro Preto: Cartulário da Sé de Coimbra. Coimbra: Arquivo da Universidade de C., 1999

\section{BIBLIOGRAFIA}

AILLET, C. (2005) - Aux marges de l'Islam: le châteaux des deux frères et le dernier des Ghassanides. In DESWARTE, T; SÈNAC, P., dirs. - Guerre, pouvoirs et idéologies dans l'Espagne chrétienne aux alentours de l'an mil. Turnhout: Brepols, p. 25-35.

AILLET, C. (2010) - Les Mozarabes. Christianisme, islamisation et arabisation en Péninsule Ibérique (IX-XII siècles). Madrid: Casa de Velázquez.

CARVAlHO, P. S., CARVALHO, A. F. (2018) - Para uma recuperação do megalitismo de Lafões (Viseu-Portugal). O concelho de Vouzela enquanto case-study. In SENNA-MARTINEZ, J. C., DINIZ, M., CARVALO, A. F. (Eds.) - De Gibraltar aos Pirenéus. Megalistismo, vida e morte na fachada atlântica peninsular. Nelas: Fundação Lapa do Lobo, pp. 37-50.

FERNANDES, A. de A. (1972) - Território e política portugalenses (séculos VI-XII). S.l. (sep. de "O Tripeiro", 4ª série, anos 10-12).

GIRÃO, A. A. (1921) - Antiguidades pré-históricas de Lafões: Contribuição para o estudo da arqueologia portuguesa. Coimbra: Imprensa da Universidade.

MARQUES, J. A. M (1999) - Carta Arqueológica do Concelho de Vouzela. Câmara Municipal de Vouzela.

MATTOSO, J. (1981) - A nobreza medieval portuguesa. Lisboa: Editorial Estampa.

REAL, M. L. (2013) - O Castro de Baiões terá servido de atalaia ou castelo, na Alta Idade Média? Sua provável relação com o refúgio de Bermudo Ordonhes na Terra de Lafões. Revista da Faculdade de Letras: Ciências e Técnicas do Património. 12, pp. 203-230.

REAL, M. L. (2018) - O papel das elites na definição progressiva do território: sua presença na senhorialização da "Fronteira Beirã" (séculos IX-XII). In TENTE, C. (Coord.) - Do Império ao Reino: Viseu e o território entre os séculos IV a XII. Viseu: Câmara Municipal de V., pp. 297-340.

TENTE, C. (2016) - A geografia diocesana entre os séculos VI a 1147. In PAIVA, J. P. (Coord.) - História da Diocese de Viseu, Vol. I - Século VI a 1505, Viseu: Diocese de Viseu, pp. 23-42.

TENTE, C. (2017) - Rock-cut graves and cemeteries in the medieval rural landscape of the Viseu region (central Portugal). In THEUNE-VOGT, C., BIS-WORCH, C. (Eds.) - Ruralia XI Conference: Religious places, cult and rituals in medieval rural environment, Leiden: Sidestone press, pp. 215-226.

VENTURA, L. (1985) - O cavaleiro João Gosendes: sua trajectória político-social e económica (1083-1116). Revista de História-Económica e Social, 1, Lisboa, pp. 31-69. 


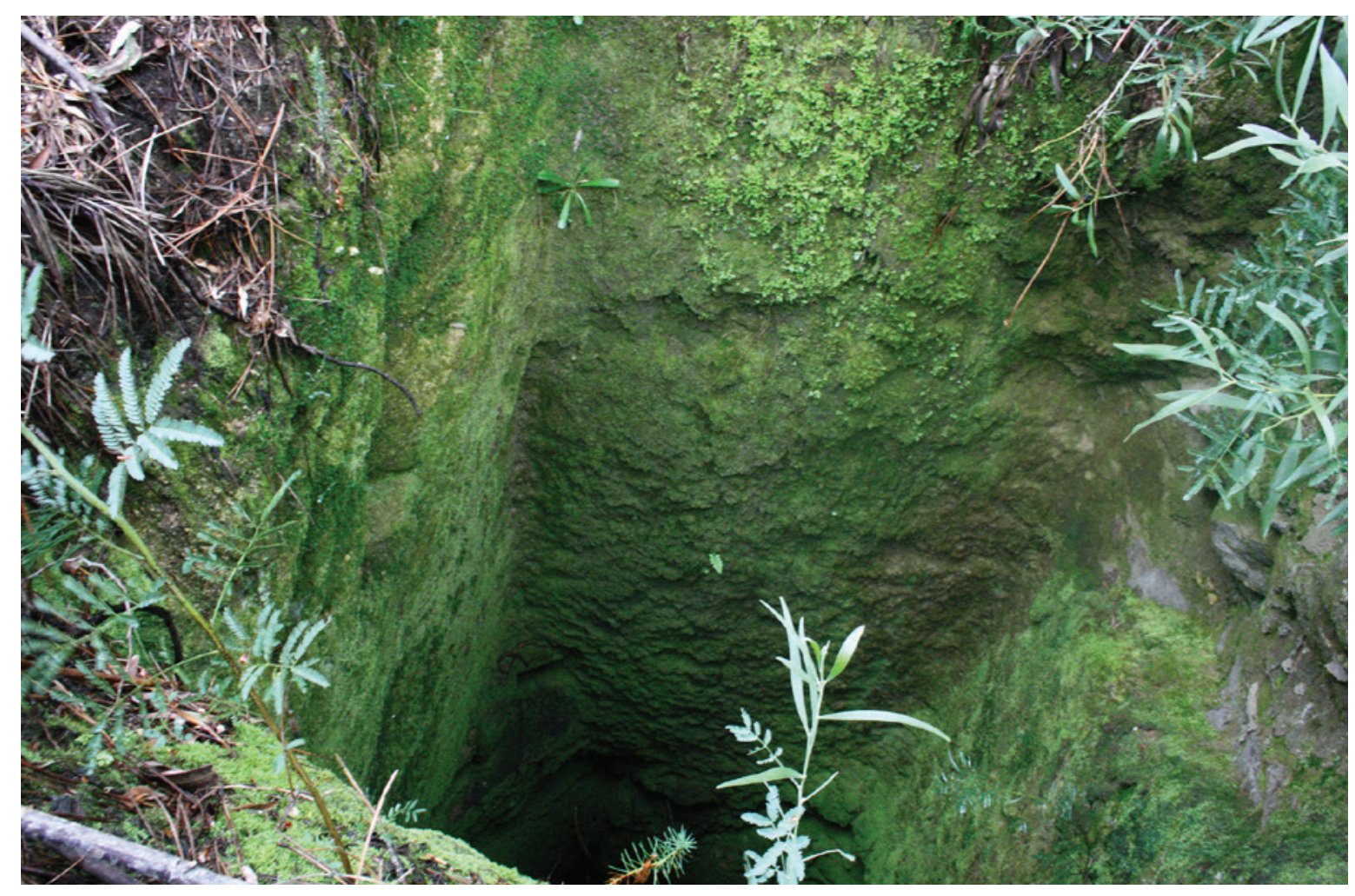

Figura 1 - Poço de mina na Senhora do Castelo, em Vouzela (cl. M. L. Real).

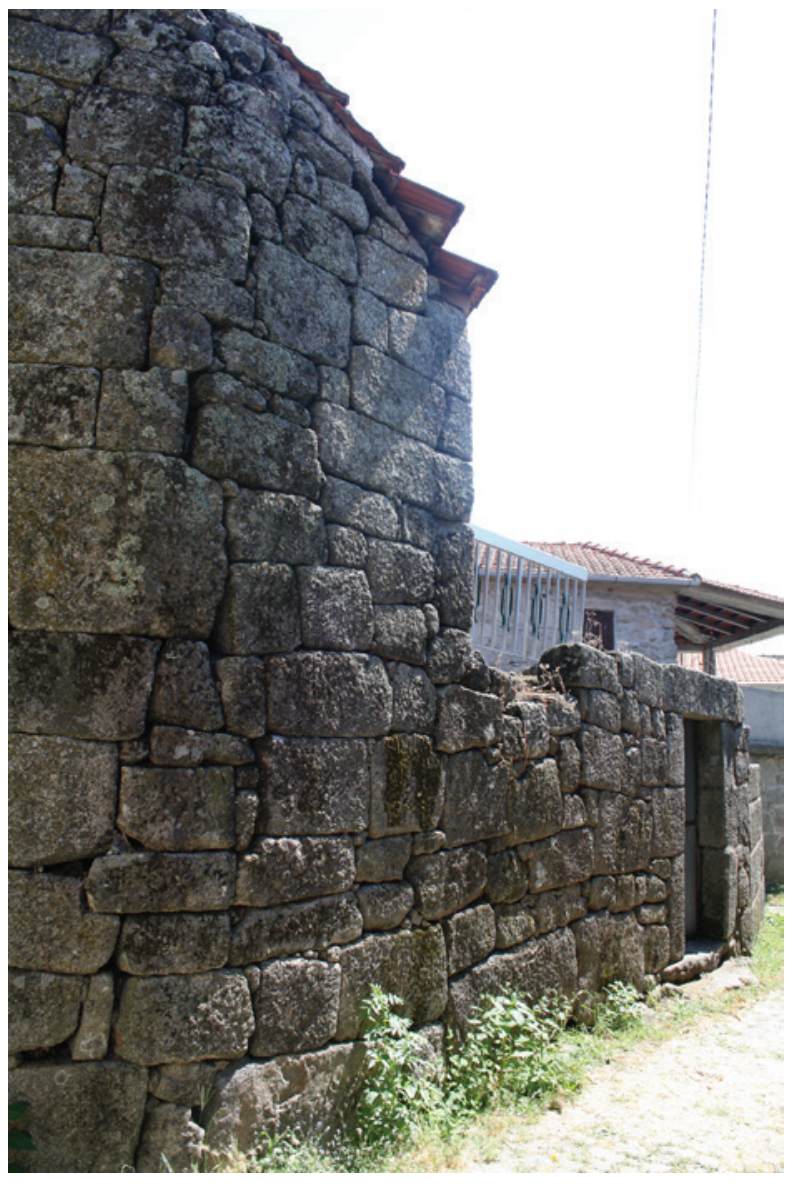

Figura 2 - Muro arruinado da torre pre-românica de Loumão, em Queirã (cl. M. L. Real). 
ESTUDO DO PATRIMÓNIO HISTOORICO-ARQUEOLOGICO DE VOUZELA TEMPLOS ANTERIORES AO SÉC. XII

$\downarrow$ Registo Documental

Vestigios Arqueológicos

ठndicios e Hagiotopónimo

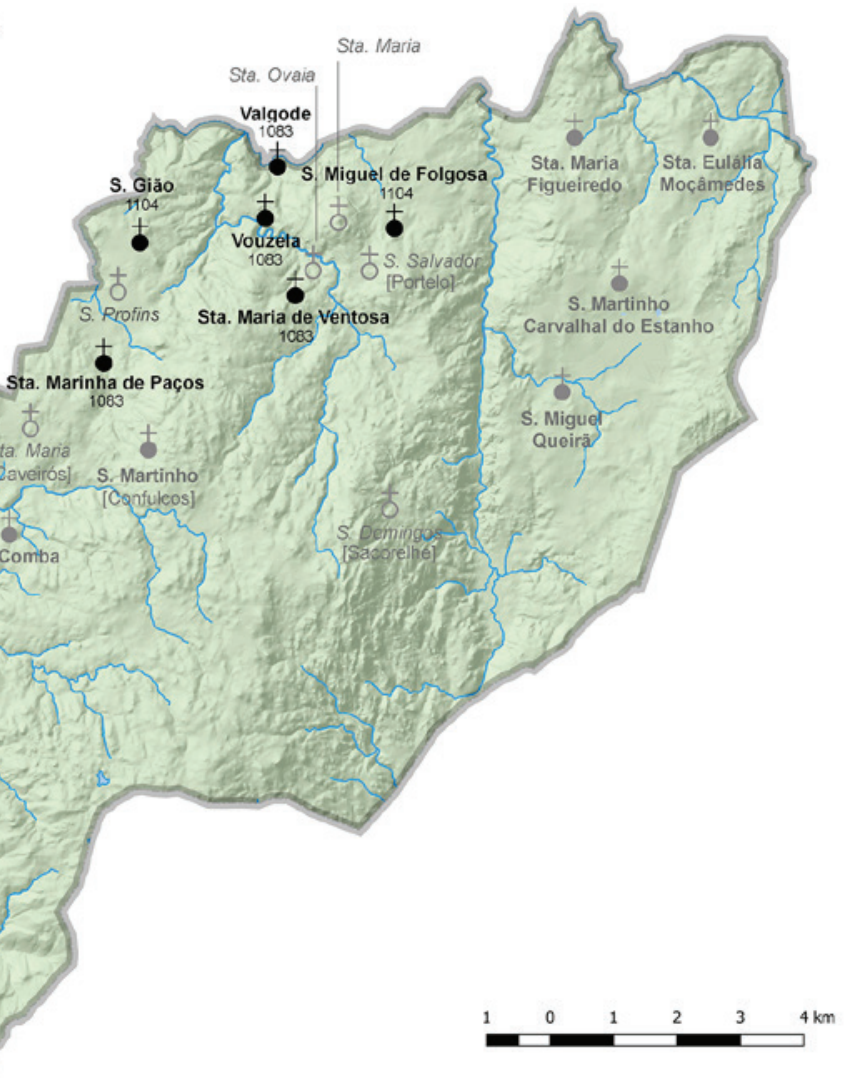

Figura 3-Templos anteriores ao séc. XII (des. Daniel de Melo Branco).

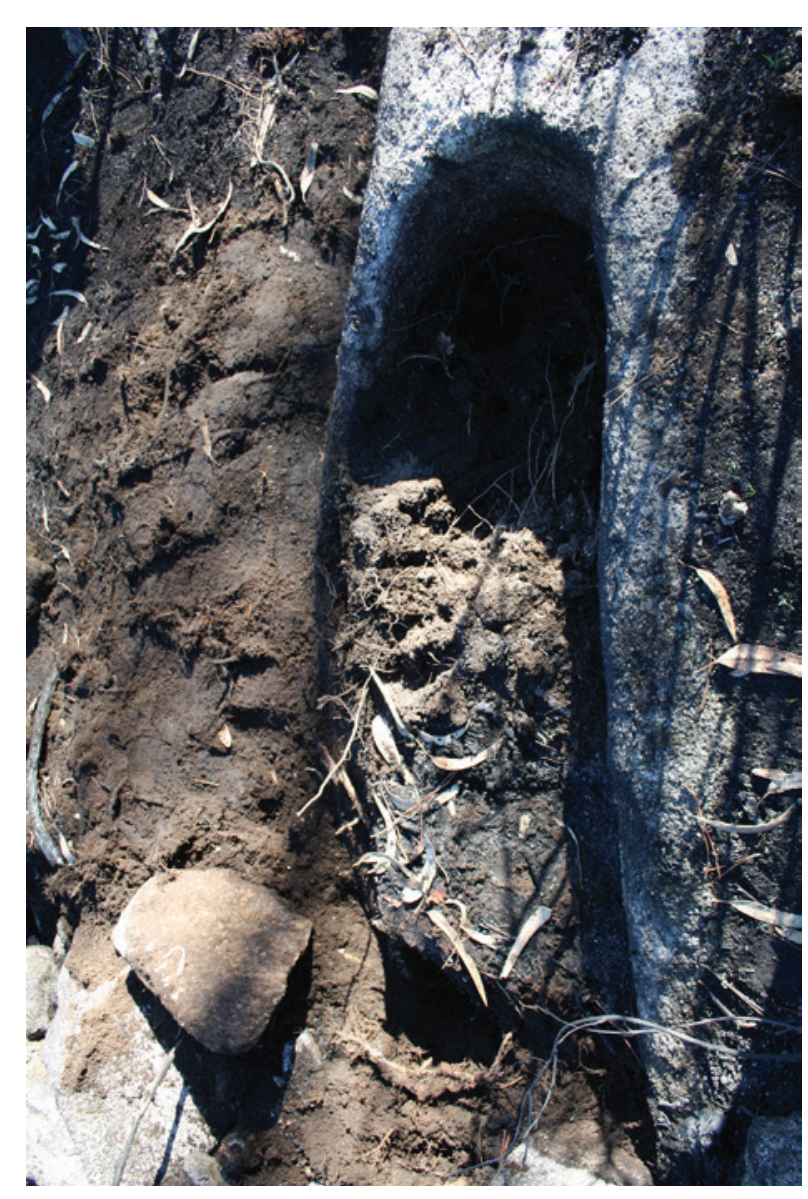

Figura 4 - Sepultura aberta na rocha, no castro da Ribamá, em Queirã (cl. M. L. Real). 


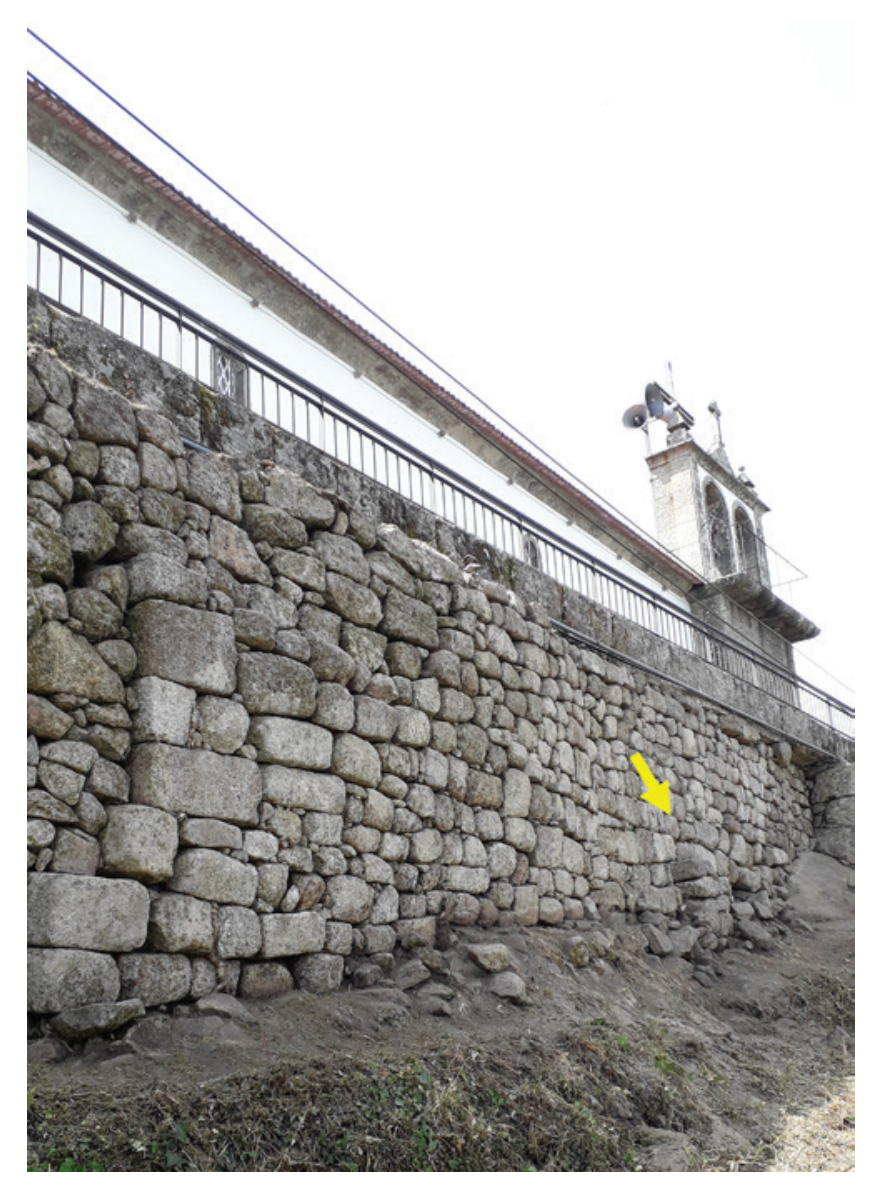

Figura 5 - Muro do castelo de Lafões. A seta aponta para o aproveitamento parcial da ruína de uma fase anterior da fortificação (cl. Luís André Pereira; trat. imag. Paulo Cruz).

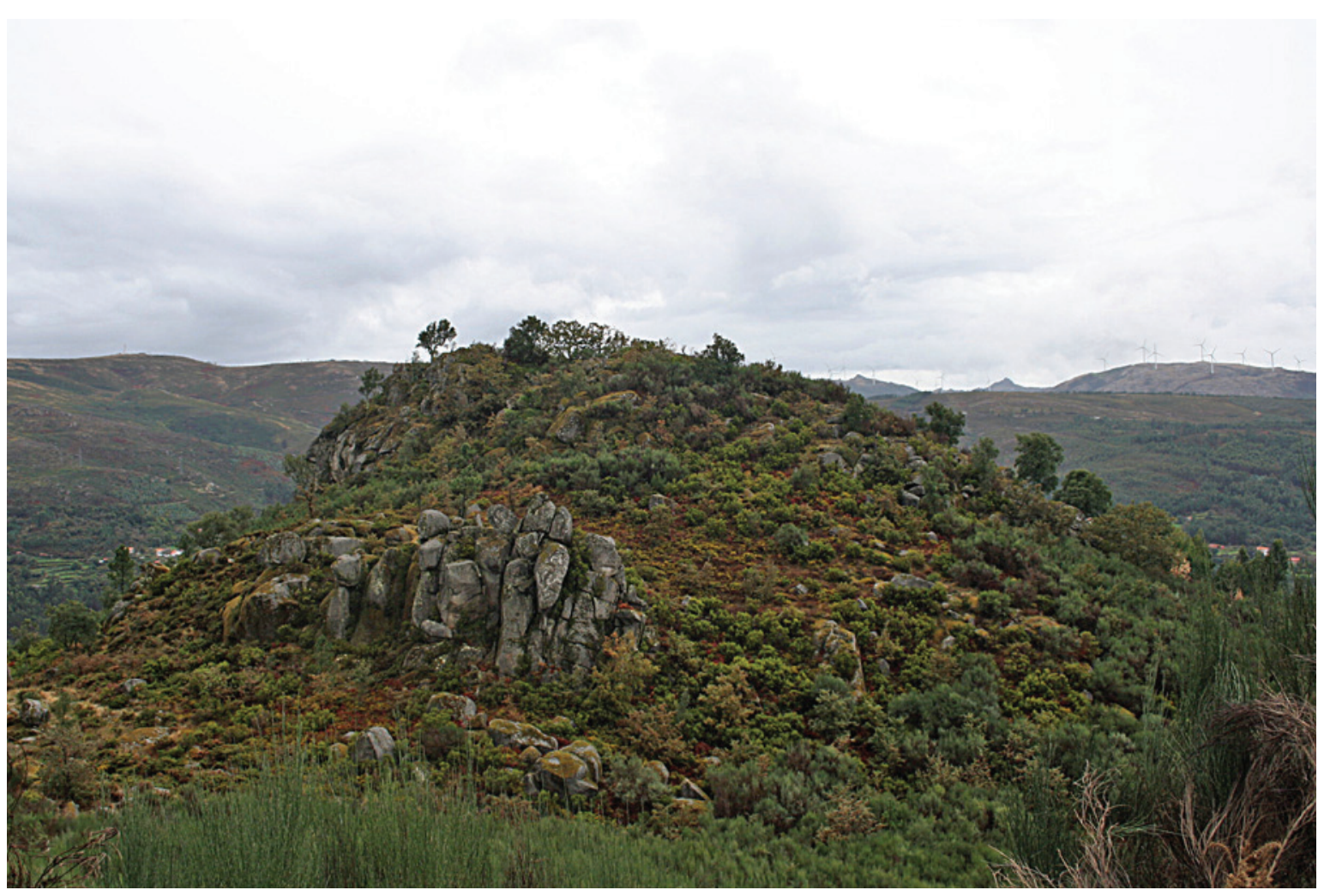

Figura 6 - O Castêlo de Alcofra, antes do incêndio de 2017 (cl. M. L. Real). 


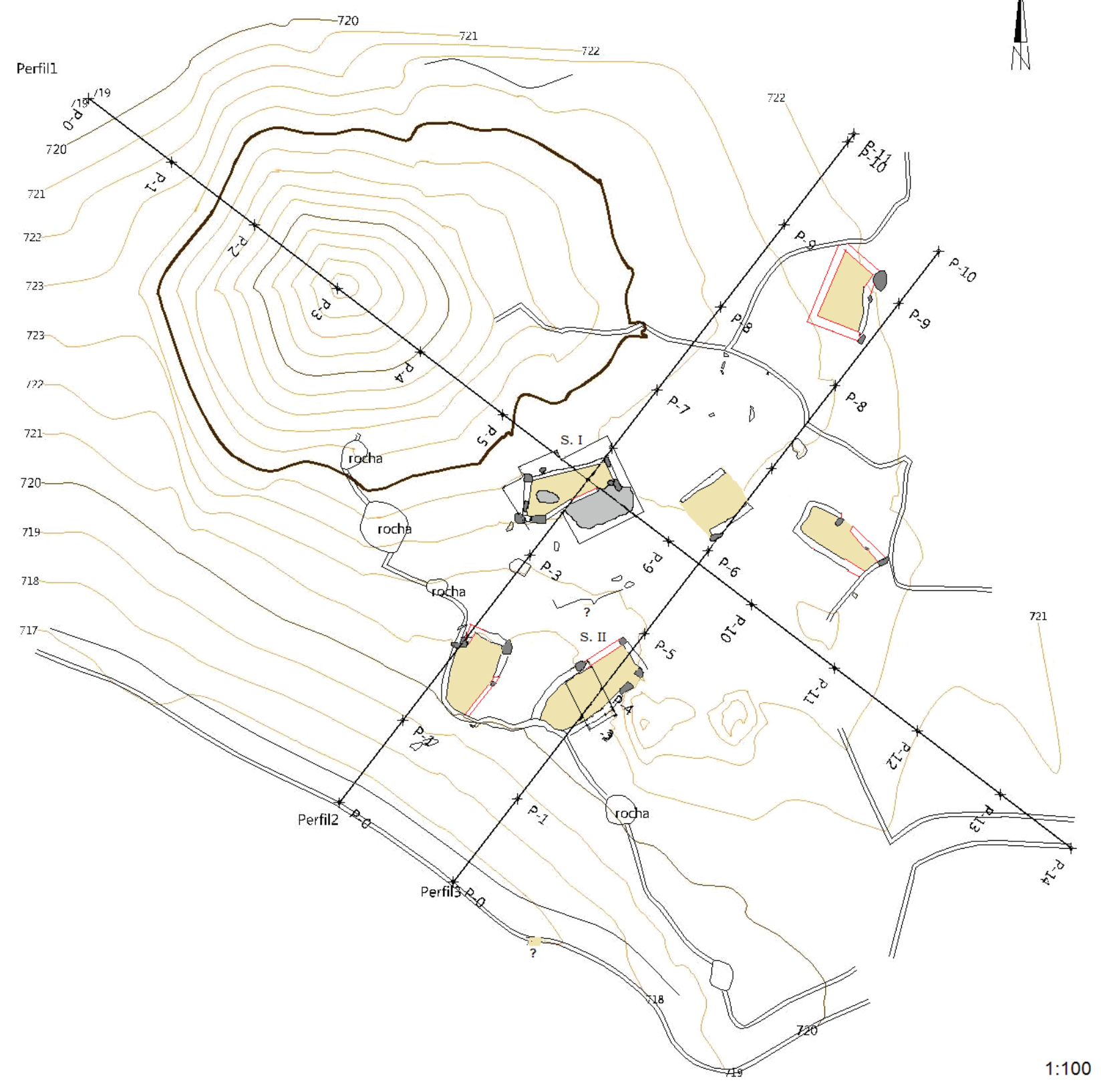

Figura 7 - Planta do habitat dos Lameiros Tapados, em Ventosa (topogr. José António Tomás; interpr. Catarina Tente). 


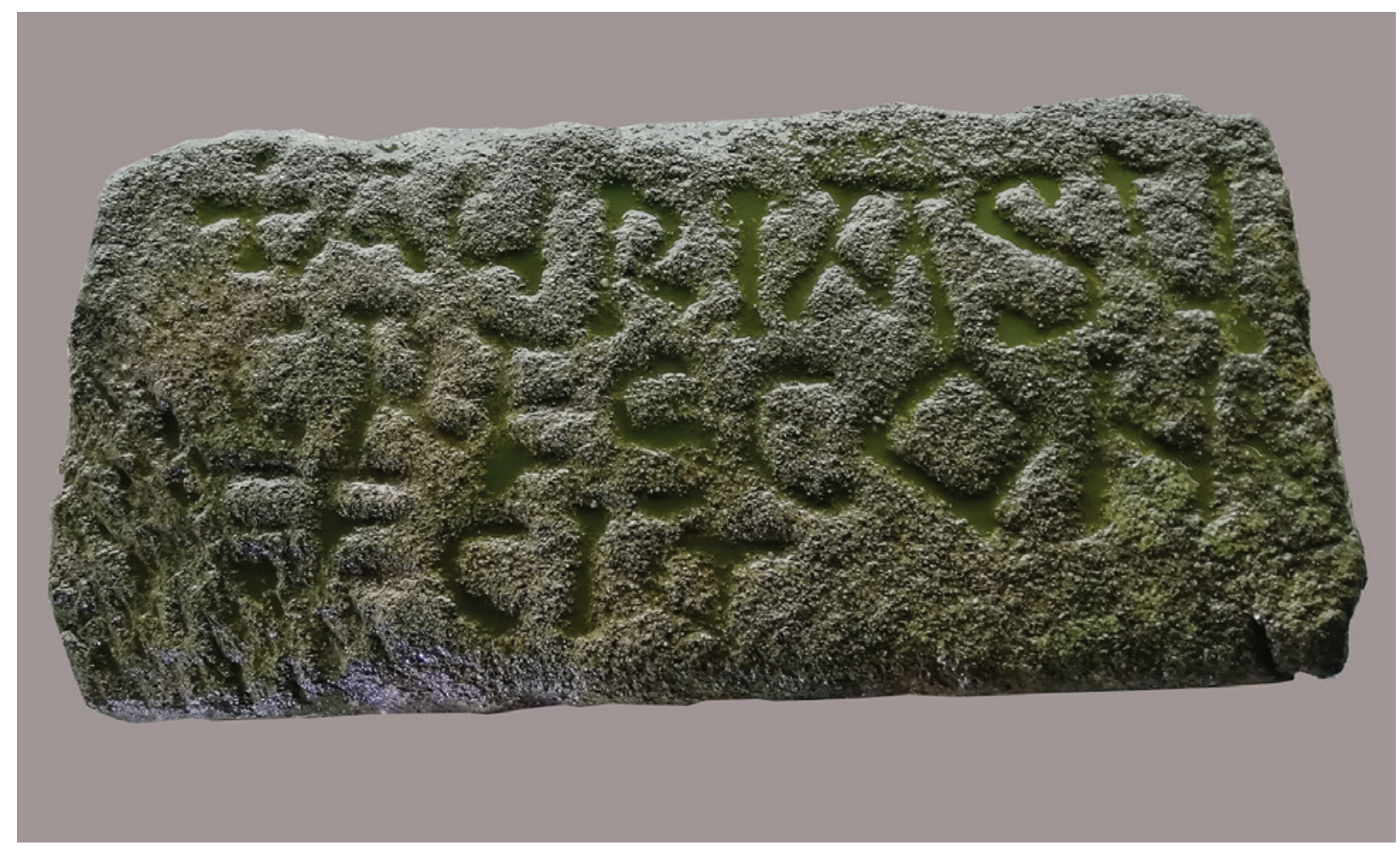

Figura 8 - Inscrição de Ṣa Maria de Figueiredo (das Donas), datável do séc. XI (cl. Luís André Pereira; trat. imag. Paulo Cruz).
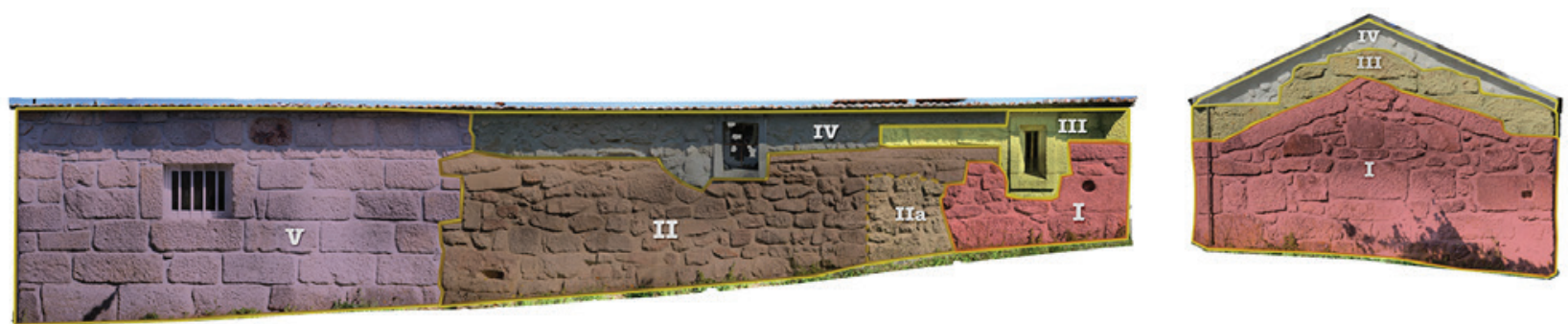

Figura 9 - Alçados Sul e Este da capela de S. Martinho de Alcofra: I - séculos V-VII ou VIII-X; II - século XI-XII; III - 1652; IV - 1960: V - 2008 (cl. Arqueologia e Património; trat. imag. Cláudio Almeida). 


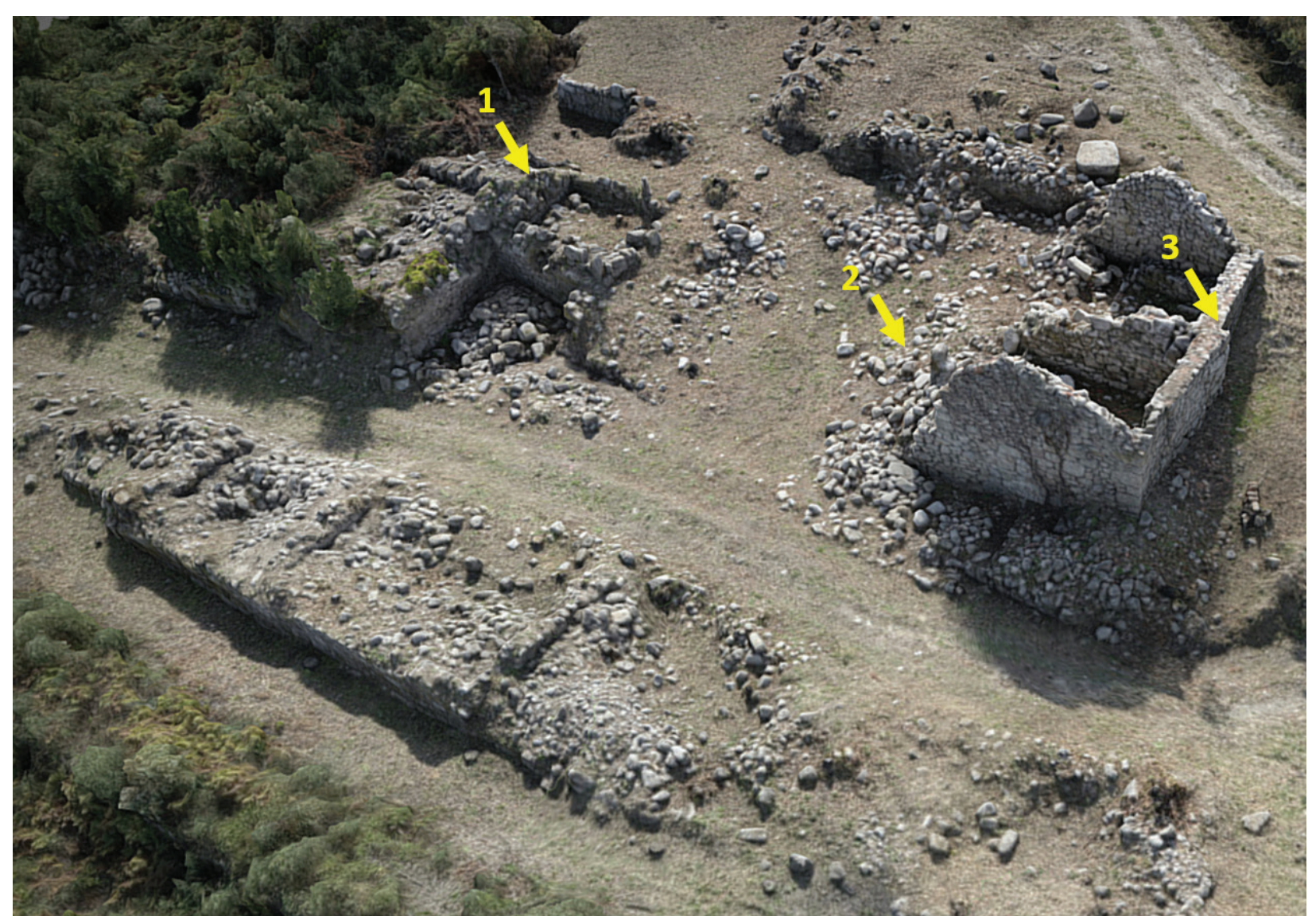

Figura 10 - Ruínas do Passal e igreja de S. Miguel de Folgosa, em Fataúnços. As setas assinalam: 1 - Presumível capela-mor do templo baixo-medieval; 2 - Provável localização da cabeceira pre-românica; 3 - Cunhal com pedras almofadadas, da igreja primitiva (cl. Arqueologia e Património; trat. imag. Paulo Cruz). 



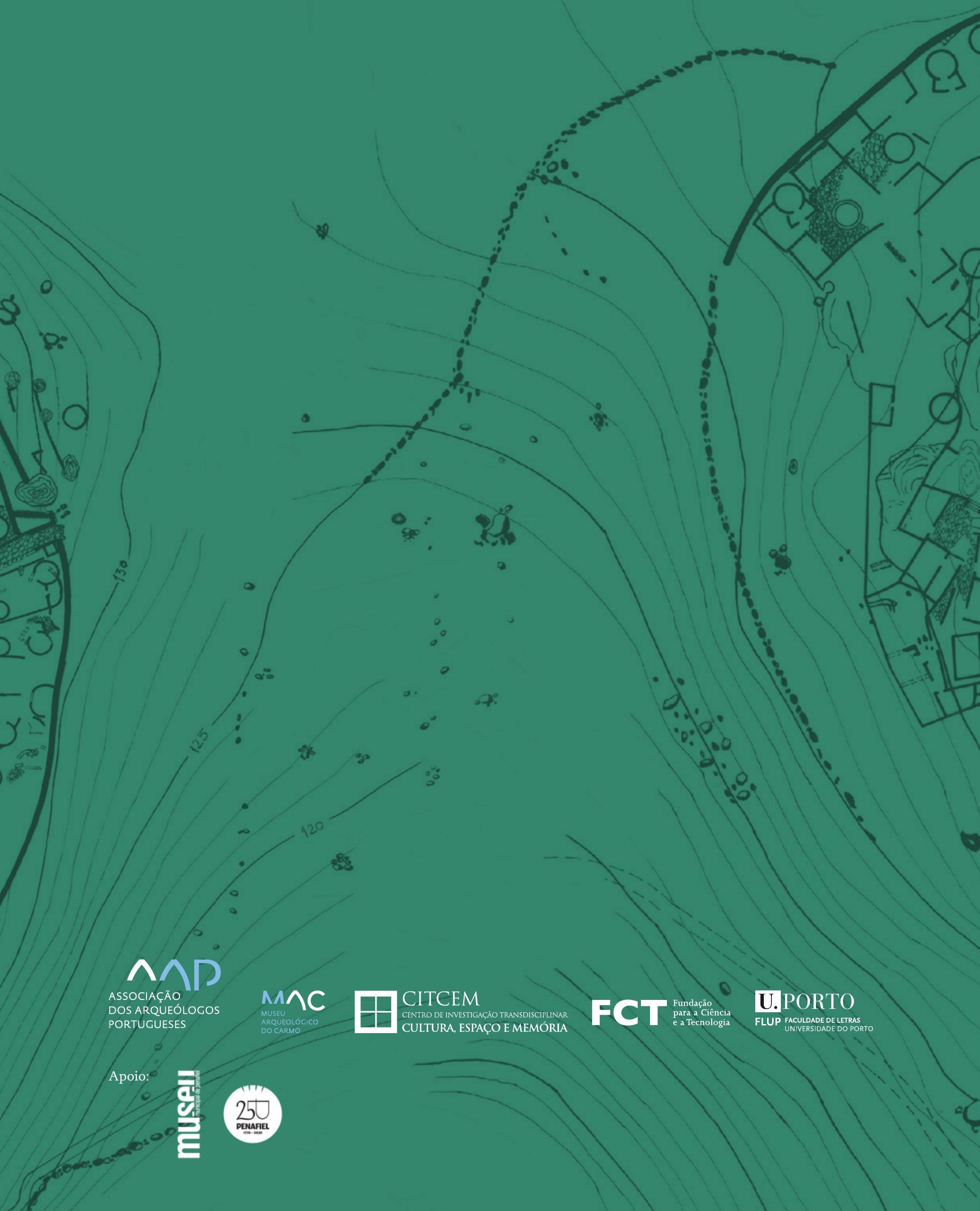

